\title{
Traumatic Alterations in GABA Signaling Disrupt Hippocampal Network Activity in the Developing Brain
}

\author{
Volodymyr Dzhala, ${ }^{1 \star}$ Guzel Valeeva, ${ }^{2,3 \star}$ Joseph Glykys, ${ }^{1 \star}$ Rustem Khazipov, ${ }^{2,3}$ and Kevin Staley ${ }^{1}$ \\ ${ }^{1}$ Department of Neurology, Massachusetts General Hospital and Harvard Medical School, Boston, Massachusetts 02114, ${ }^{2}$ National Institute of Health and \\ Medical Research, INSERM U-901, Marseille 13273, France, and ${ }^{3}$ Kazan Federal University, Kazan, Russia 420008
}

Severe head trauma causes widespread neuronal shear injuries and acute seizures. Shearing of neural processes might contribute to seizures by disrupting the transmembrane ion gradients that subserve normal synaptic signaling. To test this possibility, we investigated changes in intracellular chloride concentration $\left(\left[\mathrm{Cl}^{-}\right]_{\mathrm{i}}\right)$ associated with the widespread neural shear injury induced during preparation of acute brain slices. In hippocampal slices and intact hippocampal preparations from immature CLM-1 mice, increases in $\left[\mathrm{Cl}^{-}\right]_{\mathrm{i}}$ correlated with disruption of neural processes and biomarkers of cell injury. Traumatized neurons with higher $\left[\mathrm{Cl}^{-}\right]_{\mathrm{i}}$ demonstrated excitatory GABA signaling, remained synaptically active, and facilitated network activity as assayed by the frequency of extracellular action potentials and spontaneous network-driven oscillations. These data support a more inhibitory role for GABA in the unperturbed immature brain, demonstrate the utility of the acute brain slice preparation for the study of the consequences of trauma, and provide potential mechanisms for both GABA-mediated excitatory network events in the slice preparation and early post-traumatic seizures.

\section{Introduction}

Severe pediatric brain injuries are frequently followed by seizures in the first week after injury, with the youngest children suffering the highest incidence of seizures (Gilles and Nelson, 1998; Liesemer et al., 2011). Early seizures after brain injury exacerbate experimental injury in the developing brain (Wirrell et al., 2001) and reduce the prognosis for recovery in clinical studies of brain injury (Chiaretti et al., 2002; Keenan et al., 2007). One mechanism of acute seizures induced by brain injury may be inversion of signaling by the inhibitory neurotransmitter GABA.

GABA is an endogenous ligand of ionotropic $G_{A B A}$ receptors $\left(\mathrm{GABA}_{\mathrm{A}}-\mathrm{Rs}\right)$. $\mathrm{GABA}_{\mathrm{A}}$-Rs operate transmembrane anion-permeable channels. Depending on $\left[\mathrm{Cl}^{-}\right]_{\mathrm{i}}$ and the resting membrane potential (RMP), $\mathrm{Cl}^{-}$fluxes through $\mathrm{GABA}_{\mathrm{A}}-\mathrm{R}$-operated channels can either hyperpolarize or depolarize the membrane potential (Ebihara et al., 1995; Tyzio et al., 2008). In the adult brain, most neurons maintain low $\left[\mathrm{Cl}^{-}\right]_{\mathrm{i}}$ and are inhibited by GABA, both by virtue of membrane hyperpolarization (Ebihara et al., 1995; Tyzio et al., 2008; Glickfeld et al., 2009) and shunting (Koch et al., 1983; Staley and Mody, 1992). In immature cortical slices, $\left[\mathrm{Cl}^{-}\right]_{\mathrm{i}}$ is higher (Ben-Ari, 1987; Berglund et al., 2008; Glykys et al., 2009) and $\mathrm{GABA}_{\mathrm{A}}-\mathrm{R}$ activity has pronounced

\footnotetext{
Received Oct. 11, 2011; revised Jan. 25, 2012; accepted Jan. 29, 2012.

Author contributions: V.D. and R.K. designed research; V.D., G.V., and J.G. performed research; V.D. and G.V. analyzed data; V.D. and K.S. wrote the paper.

*V.D., G.V., and J.G. contributed equally to the paper.

This work was supported by the U.S. National Institutes of Health and National Institute of Neurological Disorders and Stroke Grant NS 40109-06 to K.S., by FRM, Agence National de la Recherche, and RF Government 11.G34.31.0075 grants to R.K., and Russian Foundation for Basic Research grant to G.V. We thank our colleagues for discussion of the manuscript.

Correspondence should be addressed to Dr. Kevin J. Staley, Department of Neurology, MIND, MGH 16th Street, CNY B-114, Room 2600, Charlestown, MA 02129. E-mail: kstaley@partners.org.

DOI:10.1523/JNEUROSCI.5139-11.2012

Copyright $\odot 2012$ the authors $\quad 0270-6474 / 12 / 324017-15 \$ 15.00 / 0$
}

excitatory as well as inhibitory effects on neuronal activity (Khalilov et al., 1999).

The dual effects of $\mathrm{GABA}_{\mathrm{A}}-\mathrm{R}$ observed in studies of developing brain tissue may be a consequence of the remarkable plasticities of neuronal $\left[\mathrm{Cl}^{-}\right]_{\mathrm{i}}$ and the reversal potential for $\mathrm{GABA}_{\mathrm{A}}-\mathrm{R}$-mediated postsynaptic currents $\left(E_{\mathrm{GABA}}\right)$. Neuronal injuries due to oxygenglucose deprivation (Inglefield and Schwartz-Bloom, 1998; Galeffi et al., 2004; Pond et al., 2006) and prolonged seizures (Khalilov et al., 2003; Dzhala et al., 2010) cause long-lasting $\left[\mathrm{Cl}^{-}\right]_{\mathrm{i}}$ accumulation and depolarize $E_{\mathrm{GABA}}$. Neuronal injuries including neurite transection, osmotic imbalance, and excess heat also depolarize $E_{\mathrm{GABA}}$ (van den Pol et al., 1996). The depolarizing actions of GABA after trauma are sufficient to activate voltage-gated calcium channels and increase the intracellular $\mathrm{Ca}^{2+}$ level (van den Pol et al., 1996), indicating that $\mathrm{GABA}_{\mathrm{A}}-\mathrm{R}$ activity excites injured neurons. To test whether the posttraumatic depolarizing actions of GABA facilitate neuronal excitability and spontaneous network-driven activity, we turned to the acute hippocampal slice preparation.

The acute hippocampal slice preparation has provided innumerable insights into synaptic physiology, but the preparation of acute brain slices necessarily involves massive trauma. Acute traumatic injury to neuronal processes during slice preparation is known to induce long-term morphological and synaptic alterations (Kirov et al., 1999; Davies et al., 2007) as well as neuronal damage, hyperexcitability, and death (Bak et al., 1980). The intact hippocampal preparation in vitro, although viable only to postnatal day 7 (P7)-P8, does not involve slicing and thus preserves morphological and functional neuronal properties (Khalilov et al., 1997). We compared the neuronal damage profile and $\mathrm{GABA}_{\mathrm{A}}-\mathrm{R}$-mediated signaling in intact and sliced hippocampal networks prepared from the same mice. $\left[\mathrm{Cl}^{-}\right]_{\mathrm{i}}$ assayed by twophoton imaging of the chloride-sensitive fluorophore Clomeleon (Kuner and Augustine, 2000) and the effect of concomitant op- 
eration of the $\mathrm{GABA}_{\mathrm{A}}-\mathrm{R}$ on action potential frequency were correlated with spontaneous neuronal network activity in both hippocampal preparations.

\section{Materials and Methods}

Animals. All animal-use protocols conformed to the guidelines of the National Institutes of Health, the Massachusetts General Hospital Center for Comparative Medicine, and the National Institute of Health and Medical Research (INSERM) on the use of laboratory animals.

Intact hippocampus and acute hippocampal slice preparations in vitro. Intact hippocampal formations were prepared from immature P5-P7 male and female CLM-1 mice pups as described previously (Khalilov et al., 1997; Dzhala et al., 2008). Animals were anesthetized and decapitated. The brain was rapidly removed to oxygenated $\left(95 \% \mathrm{O}_{2}-5 \% \mathrm{CO}_{2}\right)$ ice-cold $\left(2-5^{\circ} \mathrm{C}\right)$ artificial CSF (ACSF; solution 1) containing $126 \mathrm{~mm} \mathrm{NaCl}, 3.5 \mathrm{~mm} \mathrm{KCl}, 2 \mathrm{~mm}$ $\mathrm{CaCl}_{2}, 1.3 \mathrm{~mm} \mathrm{MgCl}_{2}, 25 \mathrm{~mm} \mathrm{NaHCO}, 1.2 \mathrm{~mm} \mathrm{NaH}_{2} \mathrm{PO}_{4}$, and $11 \mathrm{~mm}$ glucose, $\mathrm{pH}$ 7.4. The hemispheres were separated and after removing the cerebellum, the frontal part of the neocortex and surrounding structures, the intact hippocampi were dissected from the septohippocampal complex. The hippocampi were incubated in oxygenated ACSF at room temperature $\left(20-22^{\circ} \mathrm{C}\right)$ for $1-2 \mathrm{~h}$ before use. For recordings, the hippocampi were placed into a conventional submerged chamber and continuously superfused with oxygenated ACSF at $32^{\circ} \mathrm{C}$ and at a flow rate $4 \mathrm{ml} / \mathrm{min}$.

Acute hippocampal slices were prepared from P5-P29 CLM-1 mice and Sprague Dawley rats. The brain was removed from the anesthetized and decapitated animals and placed in oxygenated $\left(95 \% \mathrm{O}_{2}-5 \% \mathrm{CO}_{2}\right)$ ice-cold $\left(2-5^{\circ} \mathrm{C}\right) \mathrm{ACSF}$. Coronal and horizontal brain slices, $400-550 \mu \mathrm{m}$ thick, were cut in ice-cold oxygenated ACSF (solution 1) using a Leica VT1000S vibrating-blade microtome. In some experiments slices were prepared and preincubated in ACSF containing a high concentration of bumetanide (100 $\mu \mathrm{M})$ to block NKCC1 $\left(\mathrm{Na}^{+}-\mathrm{K}^{+}-2 \mathrm{Cl}^{-}\right.$cotransporter isoform 1) and $\mathrm{KCC} 2$ $\left(\mathrm{K}^{+}-2 \mathrm{Cl}^{-}\right.$cotransporter isoform 2) cotransporters (solution 2). Some slices were cut in high-sucrose solution (solution 3 ) containing $250 \mathrm{~mm}$ sucrose, 11 mu glucose, $2 \mathrm{~mm} \mathrm{KCl}, 0.5 \mathrm{~mm} \mathrm{CaCl}_{2}, 7.0 \mathrm{~mm} \mathrm{MgCl}_{2}, 26 \mathrm{~mm} \mathrm{NaHCO}_{3}$ and $1.2 \mathrm{mM} \mathrm{NaH}_{2} \mathrm{PO}_{4}, \mathrm{pH}$ 7.4. Sectioning frequency was $80 \mathrm{~Hz}( \pm 10 \%)$ and sectioning speed, $0.05 \mathrm{~mm} / \mathrm{s}( \pm 10 \%)$. Slices were incubated in oxygenated ACSF at room temperature $\left(20-22^{\circ} \mathrm{C}\right)$ for $1-2 \mathrm{~h}$ before use. For electrical recordings and optical imaging, slices were placed into a conventional submerged custom-made thermostatic chamber and superfused with ACSF at $32^{\circ} \mathrm{C}$ and at a flow rate of $2-3 \mathrm{ml} / \mathrm{min}$.

In vitro electrophysiology. Extracellular field potentials were recorded in the intact hippocampal preparations in vitro using tungsten microelectrodes and low-noise multichannel amplifier (bandpass $0.1 \mathrm{~Hz}-10 \mathrm{kHz}$; $\times 1000$ ). Microelectrodes made from coated tungsten wire of $20 \mu \mathrm{m}$ diameter (California Fine Wire Company) were used for simultaneous recordings of population field activity and multiple-unit activity (MUA; $500 \mathrm{~Hz}$ high-pass filter). Root mean square noise level with an electrode placed in the perfusion solution was typically $3-4 \mu \mathrm{V}$, while the amplitude of action potentials recorded from the pyramidal cell layer ranged from this noise level up to $60-80 \mu \mathrm{V}$. silicone probes (16-channel, 50 $\mu \mathrm{m}$ separation distance between the electrodes; NeuroNexus Technologies) were used for extracellular recordings of MUA at different depths through the slice (see Fig. 5).

The signals were digitized using an analog-to-digital converter (DigiData 1322A; Molecular Devices). Sampling interval per signal was $100 \mu \mathrm{s}$ (10 kHz). pCLAMP 9.2 (Molecular Devices), Mini Analysis 5.6 (Synaptosoft) and Origin 7.5 SR6 (Microcal Software) programs were used for the acquisition and data analysis.

Clomeleon imaging and $\left[\mathrm{Cl}^{-}\right]_{i}$ determination. Clomeleon is a fusion protein comprising the $\mathrm{Cl}^{-}$-sensitive yellow fluorescent protein (YFP) and the $\mathrm{Cl}^{-}$-insensitive cyan fluorescent protein (CFP). Transgenic CLM1 mice expressing Clomeleon were received from Duke University Medical Center (Durham, NC) and housed at Massachusetts General Hospital Center for Comparative Medicine (Charlestown, MA). Intact hippocampi were prepared from immature (P5-P7) mice as described previously (Dzhala et al., 2008). The hippocampi were incubated in oxygenated ACSF at room temperature $\left(20-22^{\circ} \mathrm{C}\right)$ for at least $1 \mathrm{~h}$ before use. For optical imaging and simultaneous extracellular field potential recordings, the hippocampus was placed into a conventional submerged chamber on a precision $x-y$ stage mounted on the microscope and continuously superfused with oxygenated ACSF at $32^{\circ} \mathrm{C}$ and at a flow rate 4 $\mathrm{ml} / \mathrm{min}$. Two-photon Clomeleon imaging was performed on an Olympus Fluoview 1000MPE with pre-chirp excitation optics and a fast acousto-optical modulator mounted on an Olympus BX61WI upright microscope using an Olympus $25 \times$ water-immersed objective (XLPLN $25 \mathrm{xW}$; numerical aperture (NA), 1.05). A mode-locked titanium/sapphire laser (MaiTai; Spectra-Physics) generated two-photon fluorescence with $860 \mathrm{~nm}$ excitation. Emitted light passed through a dichroic mirror (460 nm cutoff) and was bandpass filtered through one of two emission filters, $480 \pm 15 \mathrm{~nm}$ (D480/30) for CFP and $535 \pm 20 \mathrm{~nm}$ (D535/40) for YFP (FV10MP-MC/Y). Detectors containing two photomultiplier tubes were used. Image size $(X-Y$ dimension $)$ was $512 \times 512$ pixel or unit converted $254.46 \times 254.46 \mu \mathrm{m}$. Clomeleon-expressing neurons were sampled $0-200 \mu \mathrm{m}$ below the surface of the intact hippocampus ( $Z$ dimension: $0-200 \mu \mathrm{m}$; step size: $1-2 \mu \mathrm{m}$ ).

Quantitative measurements on 3D stacks were performed using ImageJ 1.45 software (National Institutes of Health). The CFP and YFP images were opened and their respective background value was subtracted for the $3 \mathrm{D}$ volume. Median filtering was applied to all of the 3D planes. Cells were visually identified and a ROI was drawn around the cell bodies. The ratio of the YFP/CFP fluorescence intensity was measured for each identified cell. The $\left[\mathrm{Cl}^{-}\right]_{\mathrm{i}}$ was calculated from the following equation:

$$
\left[\mathrm{CI}^{-}\right]_{\mathrm{i}}=K_{D}^{\prime} \frac{\left(R_{\max }-R\right)}{\left(R-R_{\min }\right)},
$$

where $R$ is the measured YFP/CFP ratio, $K_{D}^{\prime}$ is the apparent dissociation constant of Clomeleon, $R_{\max }$ is the ratio when Clomeleon is not bound by $\mathrm{Cl}^{-}$and $R_{\min }$ when it is completely quenched by $\mathrm{F}^{-}$(Kuner and Augustine, 2000; Berglund et al., 2008). The constants $K_{\mathrm{D}}^{\prime}, R_{\max }$, and $R_{\min }$ were determined from the calibration of $\left[\mathrm{Cl}^{-}\right]_{\mathrm{i}}$ using solutions of known concentrations of $\mathrm{Cl}^{-}\left(20,80\right.$, and $\left.123 \mathrm{~mm}\left[\mathrm{Cl}^{-}\right]_{\mathrm{o}}\right)$. The $\mathrm{K}^{+} / \mathrm{H}^{+}$ionophore nigericin $(50 \mu \mathrm{M})$ and the $\mathrm{Cl}^{-} / \mathrm{OH}^{-}$antiporter tributyltin chloride $(100 \mu \mathrm{M})$ were used to remove transmembrane $\mathrm{H}^{+} / \mathrm{OH}^{-}$and $\mathrm{Cl}^{-}$gradients. Neurons that experienced a change in YFP/CFP intensity to each $\left[\mathrm{Cl}^{-}\right]_{\mathrm{o}}$ were used for the calibrations. The data points obtained with the different $\left[\mathrm{Cl}^{-}\right]_{\mathrm{o}}$ are described by rewriting Equation 1 as the ratiometric function:

$$
R=\frac{K^{\prime}{ }_{D} \cdot R_{\max }+\left[C I^{-}\right] \cdot R_{\min }}{\left[\mathrm{CI}^{-}\right]+K^{\prime}{ }_{D}} .
$$

$R_{\max }$ and $K_{\mathrm{D}}^{\prime}$ were free parameters, while $R_{\min }$ was determined by quenching Clomeleon with $123 \mathrm{mM} \mathrm{F}^{-}$(Kuner and Augustine, 2000; Duebel et al., 2006). The $K_{\mathrm{D}}^{\prime}$ was $91 \pm 5.43 \mathrm{~mm}, R_{\max }$ was 1.026 , and $R_{\min }$ was 0.268 .

The mean of the value of the $\left[\mathrm{Cl}^{-}\right]_{\mathrm{i}}$ was used in pseudo-color images, as the ion concentration follows a normal distribution. The distribution of the $\left[\mathrm{Cl}^{-}\right]_{\mathrm{i}}$ as a function of depth was experimentally fitted with a linear regression function, $y=A+B^{\star} x$, where $A$ - intercept, $B$ - slope; or an exponential decay function, $y=y_{0}+A 1 e^{(-\mathrm{x} / \mathrm{L} 1)}$, where $A 1$ is the maximum $\left[\mathrm{Cl}^{-}\right]_{\mathrm{i}}$, and $L 1$ represents an exponential depth constant of damage, that is, the rate at which the average neuronal $\left[\mathrm{Cl}^{-}\right]_{\mathrm{i}}$ decreases with distance from the cut edge of the slice.

Statistics. The Shapiro-Wilk test was used to determine normality of the data. The parametric Student's $t$ test (paired and unpaired, two-tail) was used to compare normally distributed groups of data. The MannWhitney test (unpaired data, two-tail) and Wilcoxon Signed Rank test (paired data) were used for non-normally distributed data. One-way repeated-measures ANOVA (one-way ANOVA) was used to compare normally distributed data with similar variances. The level of significance was set at $p<0.05$. Group measures are expressed as mean \pm SEM; error bars also indicate SEM.

Drugs. Reagents were purchased from Sigma-Aldrich Inc. and Tocris Bioscience Cookson Inc., prepared as stock solutions, and stored before use as aliquots in tightly sealed vials at the manufacturers' recommended temperatures and conditions. VU0240551 (N-(4-methylthiazol-2-yl)-2(6-phenylpyridazin-3-ylthio)-acetamide) was a gift from Dr. Eric Delpire (Vanderbilt University, Nashville, TN). 


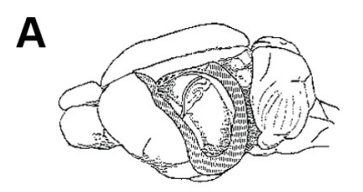

B
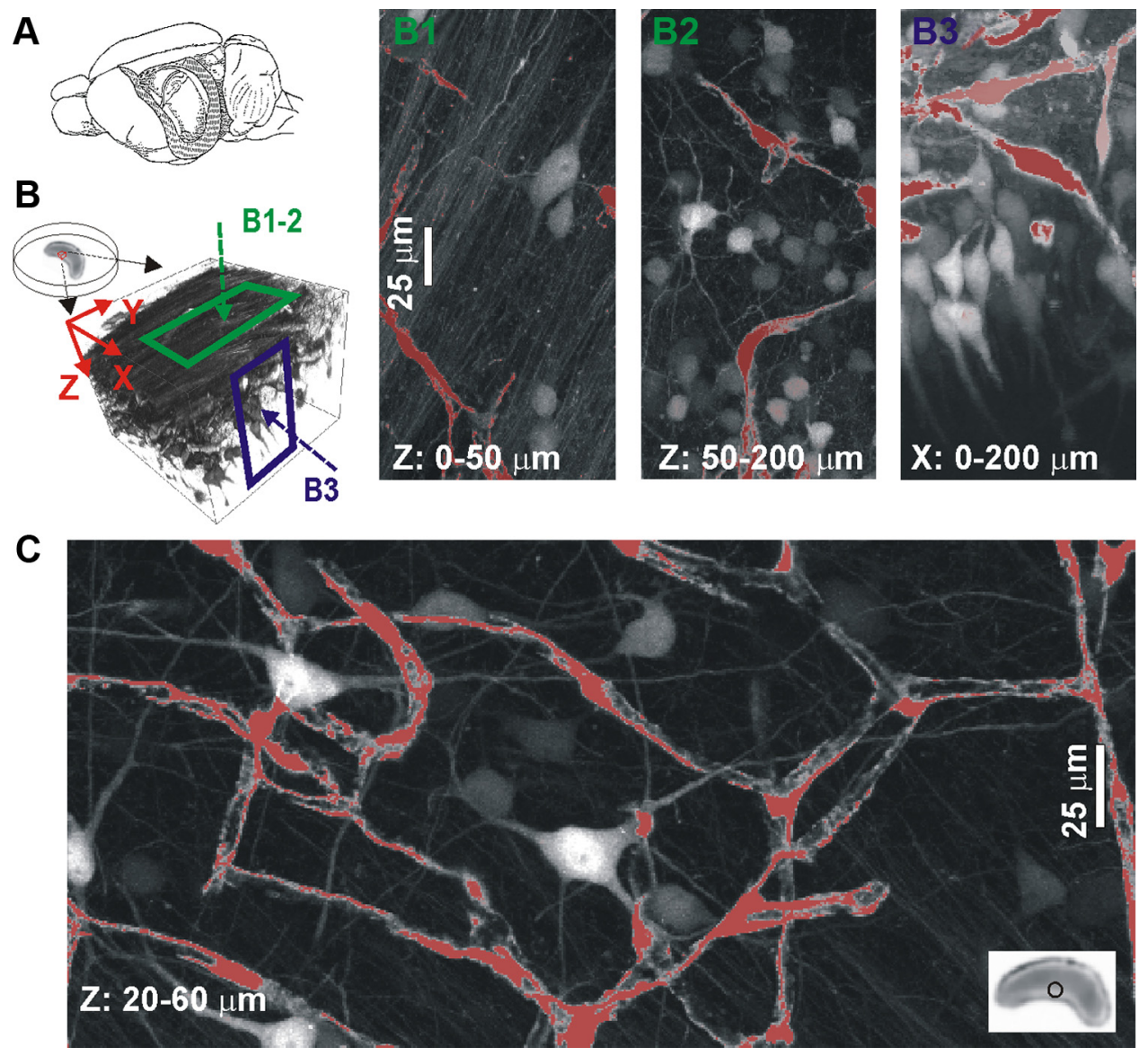

Figure 1. Preservation of neuronal structure in the intact hippocampal preparation. $\boldsymbol{A}$, Representation of the intact hippocampus and acute hippocampal slice preparations in relation to the mouse brain. $\boldsymbol{B}$, High-resolution two-photon fluorescence confocal scanning imaging of Clomeleon in the intact hippocampus from immature (P7) transgenic CLM-1 mouse. 3D view of the CA3 and proximal CA1 regions is shown. $B$ 1-B3, Horizontal $(Z=0-50$ and $50-200 \mu \mathrm{m})$ and transverse $(X=0-200 \mu \mathrm{m})$ projections from confocal scanning imaging showing remarkable preservation of neuronal structure in the intact hippocampal preparation. Numerous neurons are clearly visible in stratum oriens and pyramidal cell layers. $C$, Two-photon imaging of $C$ lomeleon in the intact hippocampal preparation from P6 CLM-1 mouse. YFP emission 20-60 $\mu \mathrm{m}$ below the surface is shown. Neurons extend dendrites in the longitudinal (septo-temporal) and transverse (caudalrostral) planes. No evidence of neuronal damage was observed. B1-B3, C, Blood vessels are shown in red.

\section{Results}

Morphological features of neuronal injury in acute hippocampal slices from immature CLM-1 mice

The intact hippocampus and acute hippocampal slices (Figs. 1, 2) were prepared from the left and right hemispheres of immature (P5P7) CLM-1 mice expressing Clomeleon $(N=12)$ (Kuner and Augustine, 2000). High-resolution two-photon fluorescence confocal scanning imaging of neurons expressing Clomeleon was performed 0-200 $\mu \mathrm{m}$ ( $z$-dimension, $0-200 \mu \mathrm{m}$; step size, $1-2 \mu \mathrm{m})$ below the surface, including the superficial outer layer $(0-20 \mu \mathrm{m})$, the intermediate layer $(20-60 \mu \mathrm{m})$ and the deep inner layer $(60-200 \mu \mathrm{m})$ (Figs. 1, 2). In the intact hippocampus, commissural fibers in the alveus were remarkably preserved in the outer layer (Fig. 1B). Numerous interneurons and pyramidal cells expressing Clomeleon were clearly visible in the stratum oriens and stratum pyramidale. Virtually all interneurons in stratum oriens extended dendrites in the longitudinal and transverse plane and/or to the deep pyramidal cell layer (Fig. 1C). Pyramidal cells projected apical dendrites to stratum radiatum and, in keeping with results of a previous study (Khalilov et al., 1997), did not show anatomical signs of traumatic injury.

In contrast to the intact hippocampal preparations, numerous neurons with morphological features of cell injury were observed in the superficial stratum oriens and pyramidal cell layers in the acute hippocampal slice preparations (Fig. 2A,B). Morphological evidence of cell damage included swollen cell bodies with absent or poorly visualized dendrites and dark (pyknotic) cells (Bak et al., 1980). Dendritic swelling (dystrophy) and beadings (varicosities) (Hasbani et al., 1998) were widespread in the superficial layer of the acute hippocampal slices. However, in the deep $(60-200 \mu \mathrm{m})$ planes in the acute slices, the cell bodies of pyramidal cells in the CA3 and CA1 regions were densely packed, morphologically preserved and healthy (Fig. $2 A$ ). The apical dendrites of these deeper neurons could be clearly visualized to extend throughout the stratum radiatum. Several interneurons with extended dendrites were apparent at this depth in the stratum oriens and stratum radiatum (Fig. 2C). However, in one hippocampal slice most of CA3 and CA1 pyramidal cells from the deep layer projected apical dendrites along the $z$-axis, i.e., directly toward the surface, and virtually all these neurons were damaged and swollen (data not shown). Our data confirmed a widespread superficial shear injury accompanying slice preparation and well preserved neurons in the inner layers of slices (Bak et al., 1980).

\section{Correlation between cell volume and a biomarker of apoptosis}

Swelling in both the soma and dendrites are considered to be a hallmark of acute neuronal injury (Inoue and Okada, 2007). 
A

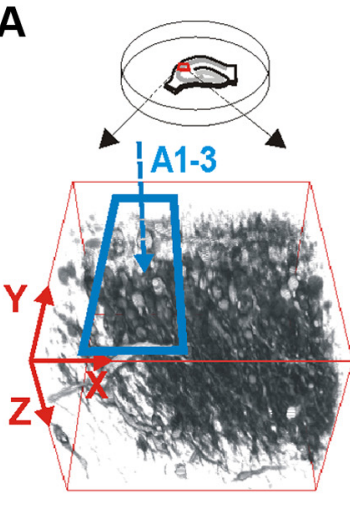

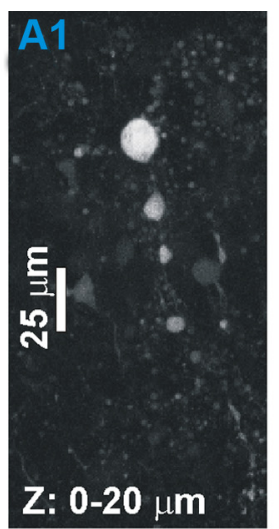

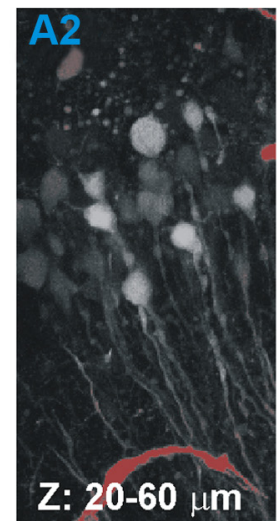

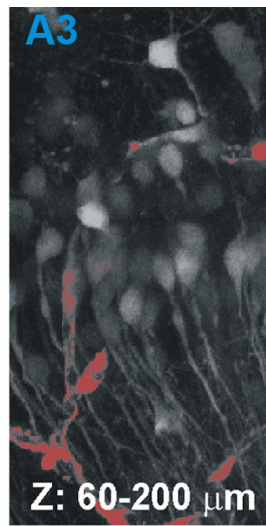

C

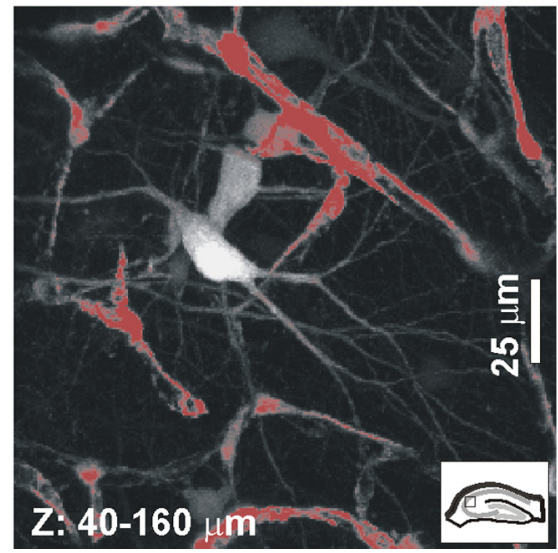

Figure 2. Morphological features of trauma-induced neuronal injury. $\boldsymbol{A}-\boldsymbol{C}$, High-resolution two-photon fluorescence confocal scanning imaging of Clomeleon in the acute hippocampal slice preparations from immature P7 $(\boldsymbol{A})$ and P6 ( $\boldsymbol{B}, \boldsymbol{C})$ transgenic $C L M-1$ mice. Blood vessels are shown in red. $\boldsymbol{A} 1, \boldsymbol{A} 2, \boldsymbol{B}$, Horizontal superficial projections $(0-20,20-60 \mu \mathrm{m}$ and $0-50 \mu \mathrm{m}$ from confocal scanning imaging in acute hippocampal slices are shown. Morphological evidence of cell damage includes swollen cell bodies, dendritic swelling (dystrophy) and beadings (varicosities). $\mathbf{A} \mathbf{3}, \boldsymbol{C}$, YFP emission in the deep (60-200 $\mu \mathrm{m}$ and $40-160 \mu \mathrm{m}$ below the surface) pyramidal cell layer and stratum radiatum is shown. Neurons are morphologically preserved and extend arborized dendrites throughout the stratum radiatum.

High-resolution two-photon fluorescence confocal scanning imaging and $3 \mathrm{D}$ reconstruction of pyramidal cells and interneurons expressing Clomeleon were used to compare cell volumes and the degree of neuronal injury in both immature hippocampal preparations (Fig. $3 A-I$ ). In the intact hippocampal preparation, the distribution of somatic volume as a function of depth was independent of the depth and was fitted with a linear regression function (see Materials and Methods) with parameters $A=1625 \pm$ $179, B=1.72 \pm 1.82 ; r=0.33 \pm 1, p=0.38(n=137$ cells in 4 hippocampi at P6-P7; Fig. 3I). In contrast to the intact hippocampus, in acute hippocampal slices somatic volume decreased as a function depth (Fig. $3 C$ ). The mean somatic volume as a function of depth was fitted with an exponential decay function with parameters $y_{0}=1015.6 \pm 628.6, A 1=2242.7 \pm 425.5$, $L 1=92.8 \pm 69.2 ; R^{2}=0.86(n=165$ cells in 4 slices at P6-P7; Fig. 3I). These characteristic cell volume changes as a function of distance from the slicing plane suggested a nonlinear distribution of neuronal damage that was greatest in the superficial layers and least in the deepest layers in acute hippocampal slices.

Cell volume regulation is an essential function in living cells and persistent shrinkage or swelling is associated with cell injury and death (Gilles and Nelson, 1998; Inoue and Okada, 2007; Hoffmann et al., 2009). Membrane-permeable fluorochrome-labeled inhibitors of caspase activity (FLICA) were used to selectively label cells undergoing apoptosis (Lee et al., 2008; Darzynkiewicz et al., 2011). Clomeleon imaging combined with the FLICA staining and imaging was used to quantify apoptosis in both hippocampal preparations in vitro (Fig. $3 D-F$ ). In the intact hippocampus, well preserved pyramidal cells and interneurons, identified with two-photon imaging of Clomeleon, were not labeled by the FLICA probe $(N=4$ hippocampi at $\mathrm{P} 6-\mathrm{P} 7$; Fig. $3 D, F$ ). In contrast to the intact hippocampi, the FLICA probe was detected in many living neurons undergoing apoptosis in the acute hippocampal slices (Fig. 3E,F). Two-photon fluorescence confocal scanning imaging revealed that $72 \pm 21 \%$ of neurons expressing Clomeleon in the $0-40 \mu \mathrm{m}$ closest to the sliced surface were stained with FLICA $(N=4$ slices at P6-P7). The fraction of neurons sensitive to the FLICA probe progressively decreased from the outer to inner layers as a function of depth as suggested by an exponential fit to these data, with parameters $y_{0}=5.98 \pm 16.8$, $A 1=129.7 \pm 87.5, L 1=29.4 \pm 27.4 ; R^{2}=0.99$ (Fig. $\left.3 F\right)$. Cell volume analysis revealed that most of the FLICA-positive cells in the acute hippocampal slices were characterized by significantly larger cell body volume (Fig. $3 H$ ). Cell swelling persisted throughout the 1-2 $\mathrm{h}$ imaging period and cell rupture was observed in several swollen cells during time-lapsed imaging (data not shown).

\section{Correlation between neuronal damage and neuronal} chloride accumulation

Acute traumatic insult caused by the cutting during slice preparation resulted in a persistent gradient of cell swelling and damage (Figs. 2, 3 ), with neurons closest to the slice plane demonstrating the most severe injury. Changes in neuronal shape and volume may represent trauma-induced disturbances of cell volume regulation mediated by the entry of water, as well as solute. $\mathrm{Cl}^{-}$entry has been shown to be 

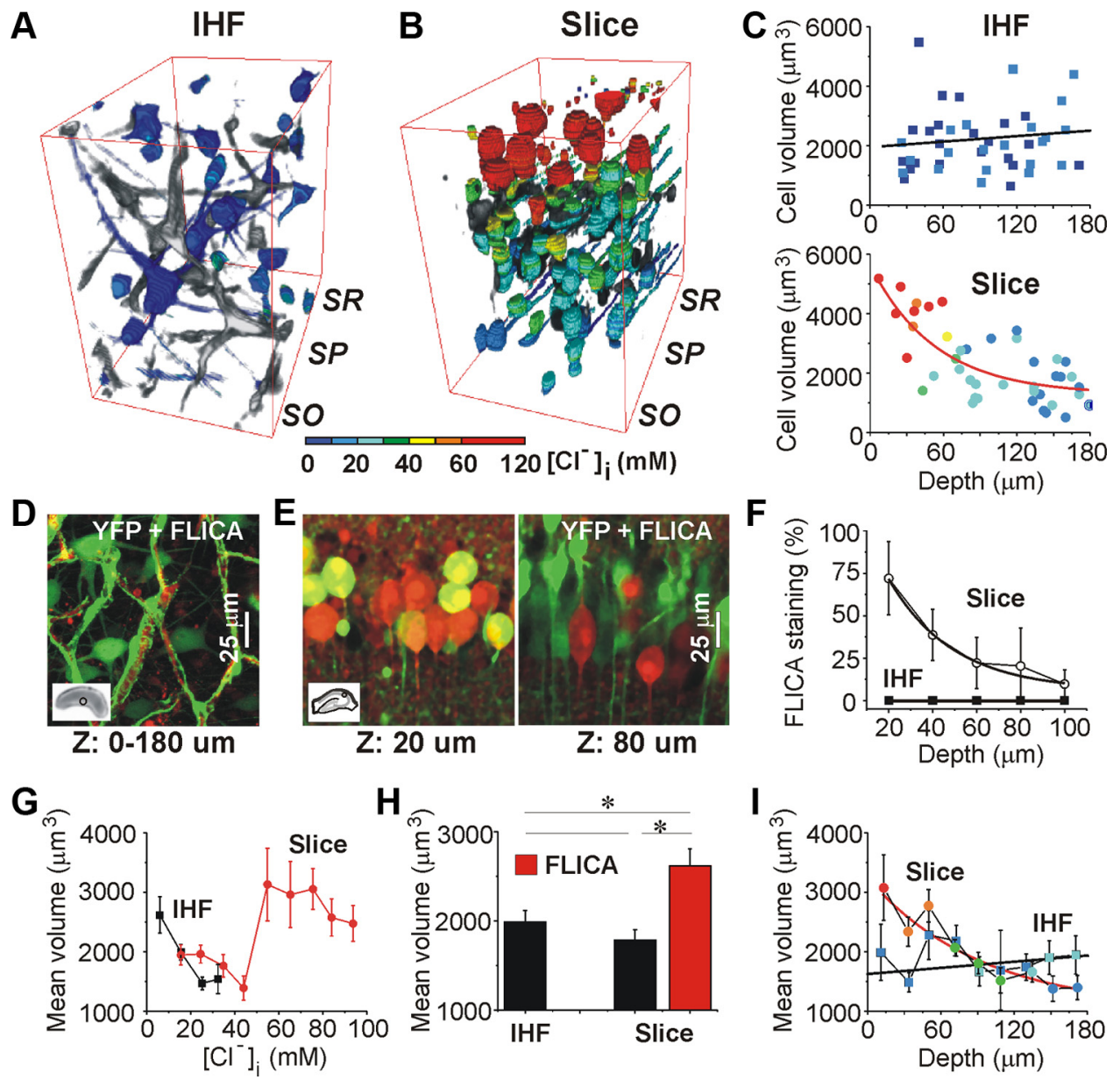

Figure 3. Correlation between cell volume, chloride accumulation and apoptosis. $\boldsymbol{A}, \boldsymbol{B}$, Three-dimensional reconstruction of neurons in the $C A 3$ regions $(X: Y: Z$ dimensions; $120 \times 180 \times 180 \mu m)$ of the intact hippocampus $(\boldsymbol{A})$ and hippocampal slice $(\boldsymbol{B})$ at P7. Neuronal cell bodies are pseudo-colored according to $\left[\mathrm{Cl}^{-}\right]_{\mathrm{i}}$ C, Color-mapped plots represent volume of reconstructed cells as a function of depth in the intact hippocampus (top) and hippocampal slice (bottom). Symbols are pseudo-colored according to $\left[\mathrm{Cl}^{-}\right]_{\mathrm{i}}$. Solid lines represent a linear regression fit (top) and an exponential function fit (bottom) to the data. D, E, YFP (green) and FLICA (red) imaging in the intact hippocampus (D) and acute hippocampal slice (E). $\boldsymbol{F}$, Percentage of YFP-expressing cells costained with FLICA in both preparations. Solid red line is an exponential function fit to the data. $G$, Relationship between somatic volume and [CI $\left.{ }^{-}\right]_{i}$ in the intact hippocampi (IHF) and acute hippocampal slice preparations. $\boldsymbol{H}$, Relationship between cell volume and FLICA staining in both preparations (mean \pm SEM; ${ }^{*}<<0.001$ ). I, Color-mapped plot represent the mean volume of reconstructed cells as a function of depth in both hippocampal preparations in vitro at P6 -P7. Data are fitted with linear regression function ( $n=4$ intact hippocampi) and exponential function ( $n=4$ slices). Symbols are pseudo-colored according to $\left[\mathrm{Cl}^{-}\right]_{\mathrm{i}}$.

a key mediator of acute excitotoxic injury marked by somatic swelling and dendritic varicosities (Rothman, 1985; Hasbani et al., 1998; Inoue and Okada, 2007). However the relationship between morphological metrics of neuronal injury and $\left[\mathrm{Cl}^{-}\right]_{\mathrm{i}}$ has not yet been determined. The ratio of FRET-dependent emission of the YFP and CFP moieties of Clomeleon was used to measure the intracellular chloride concentration in 3D-reconstructed pyramidal cells and interneurons as a function of depth in the intact hippocampus and acute hippocampal slice preparations from CLM-1 mice (Fig. 3A-C). This approach was used to correlate the cell volume as a function of intracellular chloride concentration in both hippocampal preparations(Fig. 3G,I).

In intact hippocampal preparations in vitro from immature P5-P7 CLM-1 mice, under control conditions the resting $\left[\mathrm{Cl}^{-}\right]_{\mathrm{i}}$ in individual neurons varied from 1 to $40 \mathrm{~mm}$ (Figs. 3A, C, Figs. $4 A, C$ ) and was correlated with cell volume (Fig. $3 G$ ). Gaussian multipeak fit yielded multiple peaks of steady-state $\left[\mathrm{Cl}^{-}\right]_{\mathrm{i}}$ at 10 and $20-30 \mathrm{~mm}$, suggesting heterogeneous populations of neurons (Fig. 4C), some with an equilibrium potential for chloride $\left(E_{\mathrm{Cl}}\right)$ below the RMP, and others whose $E_{\mathrm{Cl}}$ would be positive to RMP (Tyzio et al., 2003). The superficial layer $(0-50 \mu \mathrm{m})$ was characterized by lower $\left[\mathrm{Cl}^{-}\right]_{\mathrm{i}}(10.7 \pm 0.6 \mathrm{~mm} ; n=185$ cells imaged in this layer out of a total of 927 cells imaged at all depths in 8 hippocampi; Fig. $4 \mathrm{D}) \cdot\left[\mathrm{Cl}^{-}\right]_{\mathrm{i}}$ increased significantly with depth. At depths of $150-200 \mu \mathrm{m},\left[\mathrm{Cl}^{-}\right]_{\mathrm{i}}$ was $16.7 \pm 1.1 \mathrm{~mm}(n=$ 161 cells imaged at this depth out of 927 imaged cells in 8 hippocampi; $p<0.001$, Mann-Whitney test; Fig. $4 D$ ). The mean $\left[\mathrm{Cl}^{-}\right]_{\mathrm{i}}$ as a function of depth was fitted with the linear regression function with parameters $A=10.4 \pm 0.6, B=0.04 \pm 0.005 ; r=$ $0.86, p=0.006$ (Fig. $4 D$ ).

In acute hippocampal slice preparations in vitro of $\mathrm{P} 5-\mathrm{P} 7$ CLM-1 mice, the distribution of resting $\left[\mathrm{Cl}^{-}\right]_{\mathrm{i}}$ was wide and varied from 1 to $120 \mathrm{~mm}$ (Figs. $3 B, C, 4 B, C$ ). In contrast to the intact preparations, the superficial layers of hippocampal slices were characterized by higher $\left[\mathrm{Cl}^{-}\right]_{\mathrm{i}}$ and larger cell volume (Fig. $3 I$ ). In many superficial neurons $\left[\mathrm{Cl}^{-}\right]_{\mathrm{i}}$ approached extracellular chloride concentration, consistent with the common observation that superficial cells are damaged during brain slicing (Berglund et al., 2008). In several injured cells the fluorescence emission ratio of YFP to CFP was lower than the minima observed during calibration with high-chloride solutions, suggesting selective oxidation (Tsourkas et al., 2005) or other degradation of YFP in 

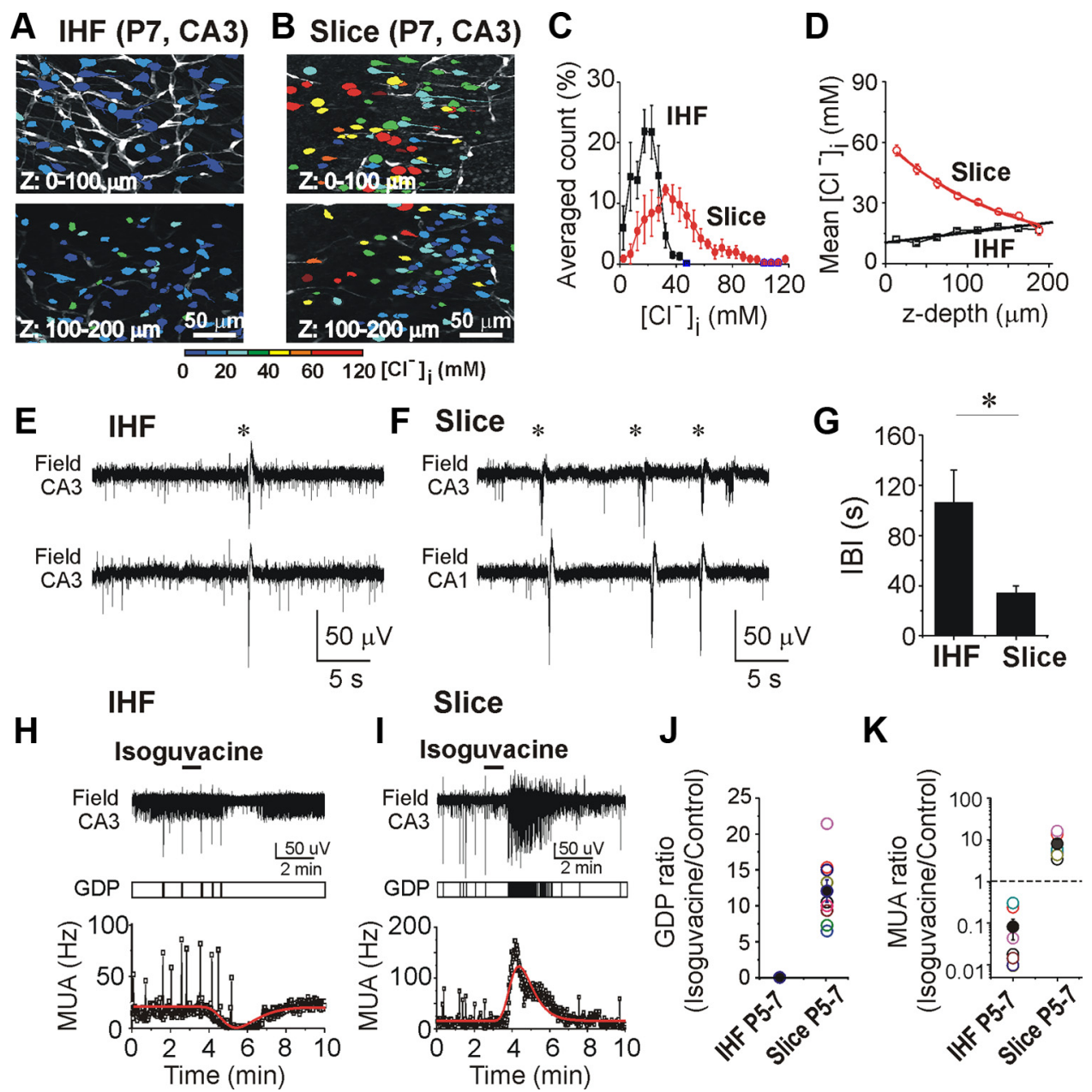

Figure 4. Chloride accumulation, neuronal network facilitation and excitatory GABA signaling in the acute hippocampal slices. $\boldsymbol{A}, \boldsymbol{B}, 0$ verlays of $0-100$ and $100-200 \mu \mathrm{m}$ two-photon fluorescence images (100 samples; $2 \mu \mathrm{m}$ step) of Clomeleon in the intact hippocampus $(\boldsymbol{A})$ and acute hippocampal slice (B) preparations in vitro of the immature (P7) CLM-1 mouse. Neurons were pseudo-colored according to the resting $\left[\mathrm{Cl}^{-}\right]_{\mathrm{i}} \cdot \mathbf{C}, \mathbf{D}$, The average $\left[\mathrm{Cl}^{-}\right]_{\mathrm{i}}$ distribution $(\boldsymbol{C})$ and the mean $\left[\mathrm{Cl}^{-}\right]_{\mathrm{i}}(\boldsymbol{D})$ as a function of depth in both hippocampal preparations at P5-P7 (mean \pm SEM; $N=8$ mice). $\boldsymbol{D}$, Data are fitted with linear regression (black) and exponential function (red). $\boldsymbol{E}-\boldsymbol{G}$, Extracellular field potential recordings from the CA3 pyramidal cell layer in both hippocampal preparations reveal multiple-unit activity and synchronous network driven bursts of population activity (marked by asterisk). $\mathbf{G}$. The mean interburst intervals (IBI) in the intact hippocampi and hippocampal slices prepared from P5-P7 mice (mean \pm SEM; $\left.{ }^{*} p=0.016, N=9\right)$. $\boldsymbol{H}, I$, Opposite effects of $G A B A_{A}$-R agonist isoguvacine (10 $\mu$ M) on population bursts (marked by vertical bars) and MUA frequency in the intact hippocampus $(\boldsymbol{H})$ and acute hippocampal slice $(\boldsymbol{I})$. Horizontal bars represent the time of solution switch. $\boldsymbol{J}, \boldsymbol{K}$, Isoguvacine to control ratio (ISO/Control) of population burst frequency and MUA frequency in the intact hippocampus and acute hippocampal slice preparations at P5-P7 (N=9 mice).

severely injured neurons. In contrast, morphologically preserved neurons in the deep layers were invariably characterized by significantly lower $\left[\mathrm{Cl}^{-}\right]_{\mathrm{i}}$ approaching the minimal observed intracellular chloride concentration. Gaussian multipeak fitting yielded sharp peaks at 20 and $40 \mathrm{~mm}$, indicating a large population of neurons whose $E_{\mathrm{GABA}}$ should be positive to RMP. Mean $\left[\mathrm{Cl}^{-}\right]_{\mathrm{i}}$ in the injured superficial $0-50 \mu \mathrm{m}$ layers in acute hippocampal slices was $50.8 \pm 1.9 \mathrm{~mm}(n=233$ cells imaged at this depth out of a total of 911 cells imaged at all depths in 8 slices) and significantly decreased to $22.1 \pm 1.5 \mathrm{~mm}(n=130$ cells at this depth out of 911 cells in 8 slices; $p<0.001$, Mann-Whitney test) in the morphologically preserved deepest 150-200 $\mu$ m layer (Fig. $4 C)$. The distribution of $\left[\mathrm{Cl}^{-}\right]_{\mathrm{i}}$ as a function of depth was fitted with the exponential function with parameters $y_{0}=1.08 \pm 9.5$, $A 1=54.6 \pm 8.9, L 1=155.9 \pm 45 ; R^{2}=0.99$ (Fig. $4 D$ ).

High $\left[\mathrm{Cl}^{-}\right]_{\mathrm{i}}$ in the superficial layers of acute hippocampal slices correlated with morphological evidence of neuronal damage and markers of activated apoptosis cascades (Fig. 3). However, many superficial neurons with no morphological evidence of cell death nevertheless had substantially higher $\left[\mathrm{Cl}^{-}\right]_{\mathrm{i}}$ than observed in the intact preparation, or in the deepest layers of the slice preparation (Figs. 3, 4). This raised the possibility that trauma-induced $\left[\mathrm{Cl}^{-}\right]_{\mathrm{i}}$ accumulation may cause a positive shift in $\mathrm{GABA}_{\mathrm{A}}$-mediated postsynaptic potential $\left(E_{\mathrm{GABA}}\right)$ in large populations of damaged neurons that remain synaptically active, which could alter network operation and contribute to seizure activity (Cohen et al., 2002; Dzhala and Staley, 2003; Dzhala et al., 2005, 2010; Mazarati et al., 2009; Wahab et al., 2011). The wide range of neuronal $\mathrm{Cl}^{-}$in presumably nontraumatized neurons in the intact hippocampal preparation also implies that both hyperpolarizing as well as depolarizing $\mathrm{GABA}_{\mathrm{A}}-\mathrm{R}$ mediated signaling occurs in distinct subpopulations of developing neurons, via inwardly and outwardly directed $\mathrm{Cl}^{-}$fluxes. However, the much larger population of neurons with elevated $\left[\mathrm{Cl}^{-}\right]_{\mathrm{i}}$ in the acute hippocampal slice vs intact hippocampus preparations at P5-P7 (Figs. 3, 4) raises the possibility of opposite network effects of $\mathrm{GABA}_{\mathrm{A}}$ receptor activation in these two preparations. We therefore compared the distribution of $\left[\mathrm{Cl}^{-}\right]_{\mathrm{i}}$ in the pyramidal cell layer with the effects of $\mathrm{GABA}_{\mathrm{A}}-\mathrm{R}$ activation on neuronal network activity in intact hippocampal preparations and acute hippocampal slices from immature (P5-P7) CLM-1 mice. 
Facilitation of neuronal network activity in acute hippocampal slice preparations from immature mice Extracellular field potential recordings of MUA and networkdriven population neuronal activity were performed in the CA3 pyramidal cell layer $(80-100 \mu \mathrm{m}$ below the surface) in intact hippocampi and acute hippocampal slices from P5-P7 CLM-1 mice. Spontaneous neuronal activity was characterized by highfrequency MUA and network-driven population bursts known as giant depolarizing potentials (GDPs) (Ben-Ari et al., 1989) (Fig. $4 E, F)$. Mean interburst intervals (IBIs) in the intact hippocampi and acute hippocampal slices prepared from the same brains at P5-P7 were $105.9 \pm 26 \mathrm{~s}$ and $33.9 \pm 5.7 \mathrm{~s}$ respectively (mean \pm SEM, $N=9$ mice; $p=0.016$, unpaired $t$ test; Fig. $4 G$ ), indicating a significantly higher probability of neuronal network-driven activity in the acute hippocampal slice preparations of the immature mice. GDP generation and propagation in the immature hippocampus involves activation of multiple polysynaptic pathways (Leinekugel et al., 1997; Sipilä et al., 2005) and depolarizing values of $E_{\mathrm{GABA}}$ may facilitate GDP generation.

\section{$\mathrm{GABA}_{\mathrm{A}}$-receptor-mediated signaling in hippocampal preparations in vitro}

The action of GABA depends on the relation between RMP and $E_{\mathrm{GABA}}$, which is mainly determined by $\left[\mathrm{Cl}^{-}\right]_{\mathrm{i}}$. The net effect of $\mathrm{GABA}_{\mathrm{A}}-\mathrm{R}$ activation on the frequency of spontaneous action potentials provides a noninvasive measurement of the net effect of synaptic $\mathrm{GABA}_{\mathrm{A}}-\mathrm{R}$-mediated signaling in neuronal networks (Cohen and Miles, 2000; Dzhala and Staley, 2003; Tyzio et al., 2007; Dzhala et al., 2008). Extracellular field potential recordings of MUA and network-driven population neuronal activity were performed in the CA3 pyramidal cell layer $(80-100 \mu \mathrm{m}$ below the surface). In the intact hippocampus and acute hippocampal slice preparations from immature P5-P7 CLM-1 mice, spontaneous neuronal activity was characterized by MUA and network-driven population bursts known as GDPs. Bath application of the selective agonist of $\mathrm{GABA}_{\mathrm{A}}-\mathrm{R}$ isoguvacine $(10 \mu \mathrm{M}$ for $1 \mathrm{~min})$ abolished spontaneous population bursts in the intact hippocampal preparations $(N=9$ hippocampi; Fig. $4 H, J)$, indicating that the net effect of activation of $\mathrm{GABA}_{\mathrm{A}}$ - $\mathrm{R}$ by exogenous agonist on immature network activity was inhibitory. In contrast, in acute hippocampal slice preparations from the same immature mice, isoguvacine transiently increased population burst frequency by $1207 \pm 156 \%(N=9$ slices; $P=0.001$; Fig. $4 I, J)$, indicating that the net effect of $\mathrm{GABA}_{\mathrm{A}}-\mathrm{R}$ activation by exogenous agonist was excitatory. Isoguvacine also had an opposite action on the frequency of spontaneous MUA in both immature preparations (Fig. $4 H, I, K)$. In line with previous data (Dzhala et al., 2010), in the intact hippocampi, bath application of isoguvacine reduced MUA frequency by $92 \pm 4 \%(N=6$ hippocampi; $p=0.001$; Fig. $4 K)$. In contrast, in the acute hippocampal slice preparations, isoguvacine transiently increased MUA frequency by $807 \pm$ 219\% $(N=8$; $p=0.008$; Fig. $4 K)$. Thus, in the immature hippocampal slice preparations post-traumatic accumulation of $\left[\mathrm{Cl}^{-}\right]_{\mathrm{i}}$ and positive shift in $E_{\mathrm{GABA}}$ correlates with increasing frequency of spontaneous network driven population bursts and inverted effects of $\mathrm{GABA}_{\mathrm{A}}$ receptor activation from inhibition to excitation.

\section{Depth- and age-dependent profile of neuronal damage and spontaneous neuronal activity}

Two-photon fluorescence imaging in the acute hippocampal slices from juvenile (P10-P14) and adult (P24-P28) CLM-1 mice demonstrated similar morphological features of cell injury
(Fig. 5A, B). Thin slices $(400-500 \mu \mathrm{m})$ of hippocampus were prepared transversely to its longitudinal septo-temporal axis. In the superficial pyramidal cell layer $(0-30 \mu \mathrm{m}$ at P10-P12 and $0-40 \mu \mathrm{m}$ at P27-P29) of acute hippocampal slices, evidence of neuronal damage included swollen cell bodies with absent or poorly visualized dendrites, as well as dendritic dystrophy and varicosity in the stratum radiatum and stratum oriens (Hasbani et al., 1998). In the intermediate layer (30-60 $\mu \mathrm{m}$ at P11-P12 and $40-80 \mu \mathrm{m}$ at P27-P29) the fraction of swollen neurons and the density of dendritic dystrophy and varicosities gradually decreased (Fig. 5A,B). Many cells in this layer exhibited preserved basal and apical dendrites, although at this depth there was still abundant evidence of dendritic beading associated with shear injury of longitudinal pathways, perpendicular to the plane of slices. In the deeper planes $(60-200 \mu \mathrm{m}$ at P11-P12 and $80-200$ $\mu \mathrm{m}$ at P27-P29) of acute slices, the cell bodies of pyramidal cells were densely packed and morphologically preserved. The arborized apical dendrites of these deeper neurons were clearly visualized to extend throughout the stratum radiatum.

We addressed the functional status of neurons in slice preparations from juvenile and adult mice by recording MUA at different depths from one to $3 \mathrm{~h}$ after slice preparation. In this experiment, we used 16-channel silicone probes (50 $\mu \mathrm{m}$ separation distance between the electrodes) inserted at $75^{\circ}$ into the CA3 pyramidal cell layer of transverse hippocampal slices prepared from P6-P29 rats (Fig. 5C-G). Spontaneous MUA was apparent at all electrodes within the slice except the superficial electrodes. The size of MUA- "silent" zones at the slice surface was calculated as $(T-((N-1) \times \sin (\alpha) \times 50 \mu \mathrm{m})) / 2$, where $T$ is an anatomical slice thickness $(550 \mu \mathrm{m}), N$ is the number of electrodes displaying MUA, $\alpha$ is an angle of electrode against the slice surface, and $50 \mu \mathrm{m}$ is the separation distance between the electrodes. The size of the MUA-silent zones was 30-60 $\mu \mathrm{m}$ during the two first postnatal weeks (mean $\pm \mathrm{SEM}, 42 \pm 2 \mu \mathrm{m} ; N=34$ slices), and it progressively increased with age to 70-90 $\mu \mathrm{m}$ by the end of the fourth week (mean $\pm \mathrm{SEM}, 81 \pm 6 \mu \mathrm{m} ; N=9$ slices) (Fig. $5 F, G$ ). MUAsilent zones were remarkably similar in size in slices at a given age, and the age-dependent depth profiles of MUA silence were similar to the superficial zones of severe neuronal injury and increased $\left[\mathrm{Cl}^{-}{ }_{\mathrm{i}}\right]$ observed using two-photon imaging.

\section{Depth- and age-dependent profiles of neuronal chloride concentration}

In acute hippocampal slices prepared from juvenile P8-P14 and adult P21-P28 mice, the distribution of resting $\left[\mathrm{Cl}^{-}\right]_{\mathrm{i}}$ in the damaged superficial layer $(0-40 \mu \mathrm{m}$ at $\mathrm{P} 8-\mathrm{P} 14$ and $0-80 \mu \mathrm{m}$ at P21-P28) was wide and varied from 40 to $120 \mathrm{~mm}$ (Fig. 6A-C). In contrast, the distribution of resting $\left[\mathrm{Cl}^{-}\right]_{\mathrm{i}}$ in the morphologically preserved population of neurons in the inner layer (150-200 $\mu \mathrm{m}$ ) was narrow and varied from 1 to $20 \mathrm{~mm}$. Gaussian fits to the $\left[\mathrm{Cl}^{-}{ }_{\mathrm{i}}\right]$ data from the inner layers yielded narrow peaks at 5-10 $\mathrm{mm}$ (data not shown), suggesting a large population of neurons with $E_{\mathrm{Cl}}$ below the expected RMP (Ebihara et al., 1995). At P8$\mathrm{P} 14$, the mean values of resting $\left[\mathrm{Cl}^{-}\right]_{\mathrm{i}}$ in the injured $0-50 \mu \mathrm{m}$ superficial layers was $51.4 \pm 1.7 \mathrm{~mm}(n=271$ imaged at this depth out of a total of 1021 cells imaged at all depths in 6 slices) and decreased in the inner 150-200 $\mu \mathrm{m}$ layer to $14.2 \pm 6.7 \mathrm{mM}$ ( $n=103$ cells imaged at this depth out of a total of 1021 imaged cells in 6 slices; $p<0.001$, Mann-Whitney test). At P21-P28, the mean values of resting $\left[\mathrm{Cl}^{-}\right]_{\mathrm{i}}$ in the injured $0-50 \mu \mathrm{m}$ superficial layers was $54.8 \pm 1.8 \mathrm{~mm}(n=334$ cells imaged at this depth out of 1692 imaged cells in 6 slices) and decreased to $4.1 \pm 0.6 \mathrm{~mm}$ 
A
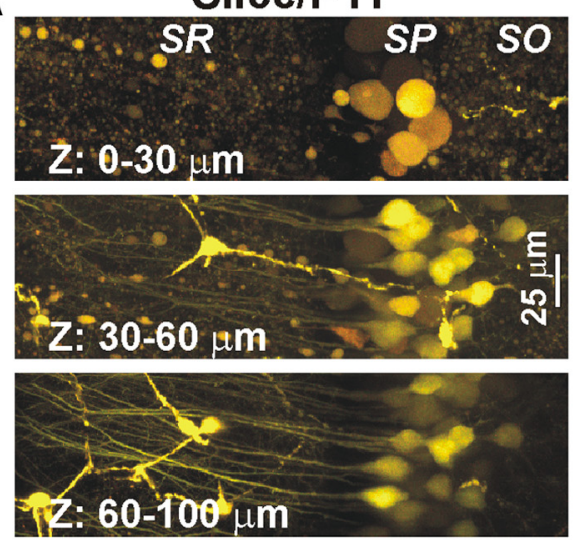

B
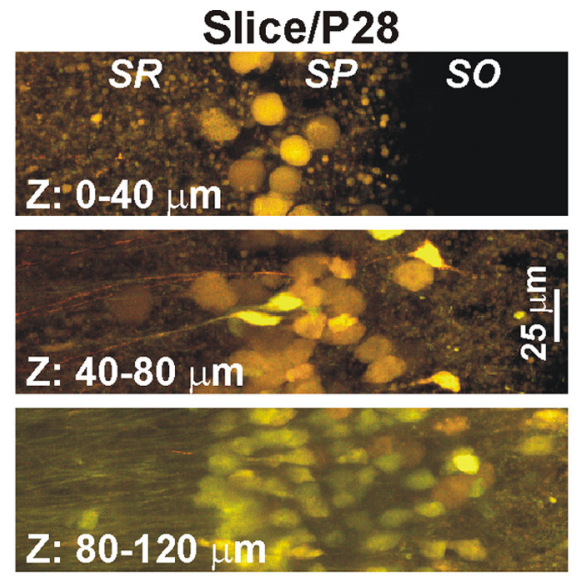
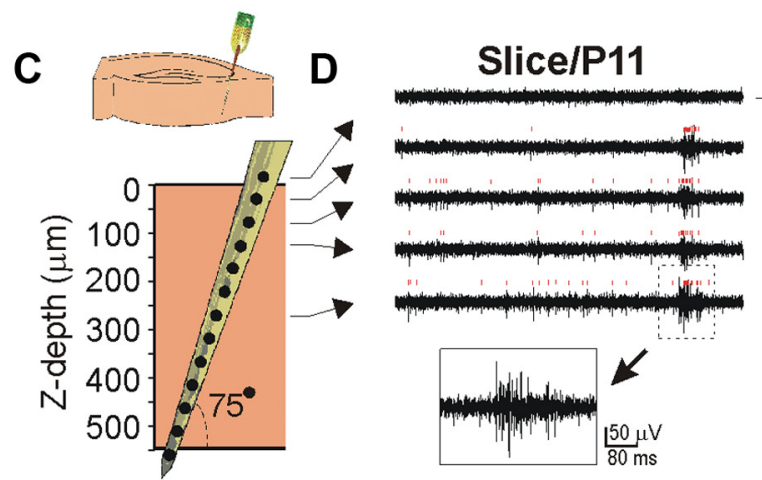

E

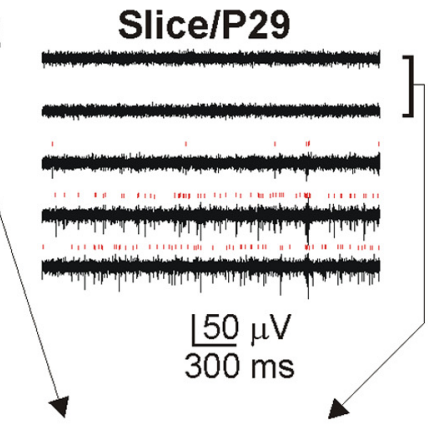

$\mathbf{F}$

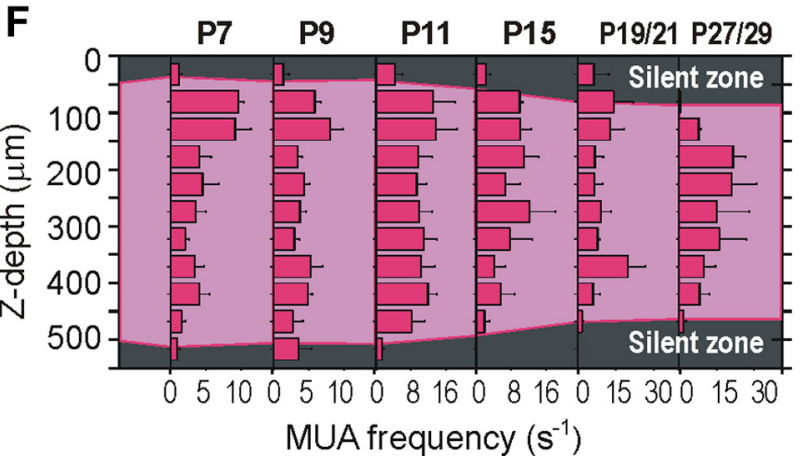

Figure 5. Depth and age-dependent profile of neuronal damage and neuronal activity in the hippocampal slices. $\boldsymbol{A}, \boldsymbol{B}$, Two-photon fluorescence images of Clomeleon in the acute hippocampal slice preparations in vitro at P11 and P28. Merged CFP and YFP emission is shown. Overlays of $0-30,30-60$ and $60-100 \mu \mathrm{m}$ ( $1 \mu \mathrm{m}$ step) multiple planes for P11 (A) and $0-40,40-80$ and $80-120$ $\mu \mathrm{m}$ for P28 (B). $\mathbf{C}-\mathbf{G}$, Depth and age dependence of MUA in the rat hippocampal slices. C, Scheme of the experimental setup: 16-channel silicone probe with $50 \mu \mathrm{m}$ separation distance between the electrodes inserted through CA3 pyramidal cell layer of a $550-\mu \mathrm{m}$-thick slice. D, E, Extracellular field potential recordings obtained at different depth in P11 and P29 slices. Each individual action current is marked by red bar above the trace. $\boldsymbol{F}$, Summary plot of the age and depth dependence of MUA frequency is shown in the outline of the MUA-active (violet) and MUA-silent (gray) zones calculated as described in the text. $\mathbf{G}$, Size of MUA-silent zones at the slice surface (averaged values for the top and bottom surfaces) as a function of age. $\boldsymbol{F}$ and $\mathbf{G}$ are based on pooled data from 5 to 9 slices in each age group.

( $n=306$ cells imaged at this depth out of a total of 1692 imaged cells in 6 slices; $p<0.001$, Mann-Whitney test) respectively. At $\mathrm{P} 8-\mathrm{P} 14$, the mean $\left[\mathrm{Cl}^{-}\right]_{\mathrm{i}}$ as a function of depth was fitted with the exponential function with parameters $y_{0}=10.5 \pm 0.6, A 1=$ $81.9 \pm 4.5, L 1=36.2 \pm 2.2 ; R^{2}=0.994$. At P21-P28, the $\left[\mathrm{Cl}^{-}{ }_{\mathrm{i}}\right]$ data were best fitted with a sigmoidal (Boltzmann) function $y=$ $A 2+(A 1-A 2) /\left(1+\exp \left(\left(x-x_{0}\right) / d x\right)\right)$, where $A 1=57 \pm 1.96$, $A 2=3.7 \pm 0.57, x_{0}=91.7 \pm 2, d x=14.85 \pm 1.45 ; R^{2}=0.9933$ (Fig. $6 D$ ). The narrow distribution and low values of resting $\left[\mathrm{Cl}^{-}\right]_{\mathrm{i}}$ in the deepest layer implies that $\mathrm{GABA}_{\mathrm{A}}-\mathrm{R}$-mediated signaling is inhibitory in most neurons in the deepest and bestpreserved layers of the hippocampal slices, via hyperpolarizing or shunting $\mathrm{Cl}^{-}$conductances.
Depth profile of $\mathrm{GABA}_{\mathrm{A}}$-receptor-mediated signaling

The increased $\left[\mathrm{Cl}^{-}\right]_{\mathrm{i}}$ in the most superficial neurons of acute hippocampal slices suggests corresponding depth-dependent changes in $\mathrm{GABA}_{\mathrm{A}}-\mathrm{R}$-mediated signaling. We therefore addressed the impact of elevated $\left[\mathrm{Cl}^{-}\right]_{\mathrm{i}}$ in the superficial vs intermediate depths of the hippocampal slices. The effects of $\mathrm{GABA}_{\mathrm{A}}-\mathrm{R}$ activation on spontaneous population burst and MUA frequency at different depth were examined using a 16-channel silicone probe in the CA3 pyramidal cell layer (Fig. $5 C$ ). Bathapplication of the selective $\mathrm{GABA}_{\mathrm{A}}-\mathrm{R}$ agonist isoguvacine $(10 \mu \mathrm{M}$ for $1 \mathrm{~min}$ ) synchronously increased GDP and MUA frequency at all recording sites throughout the slice depths at P7-P14 ( $N=16$ slices; data not shown). In keeping with previous 

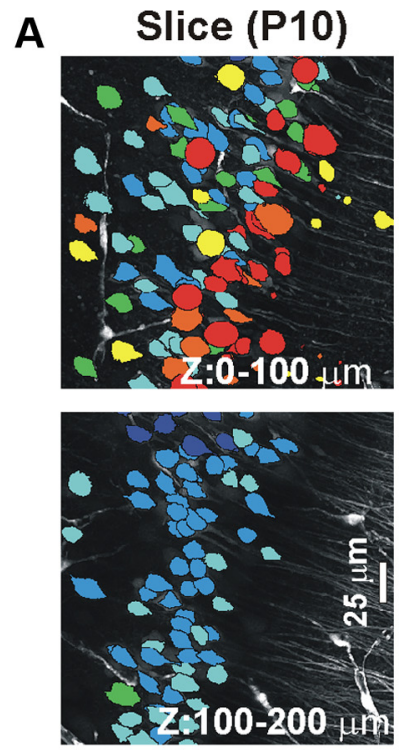
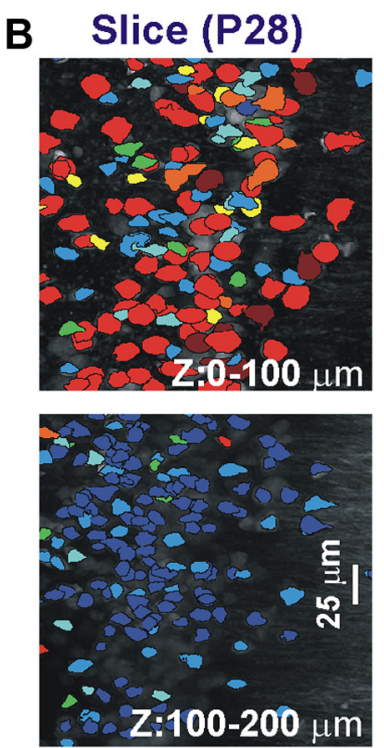

\section{C}

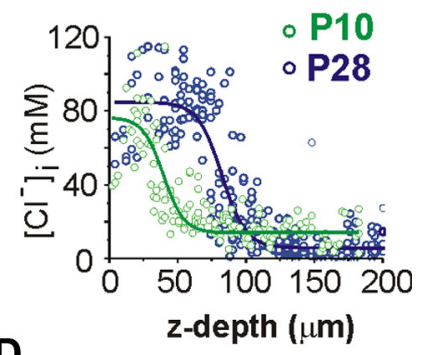

D

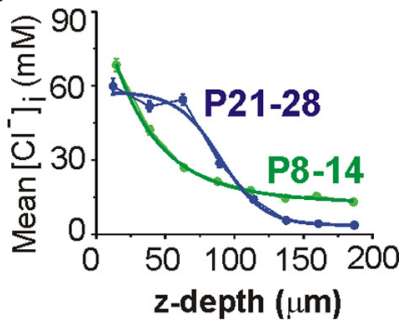

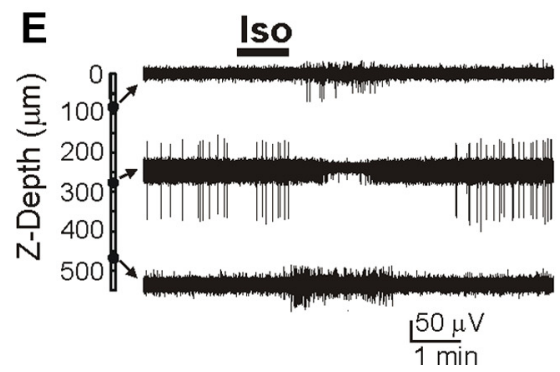
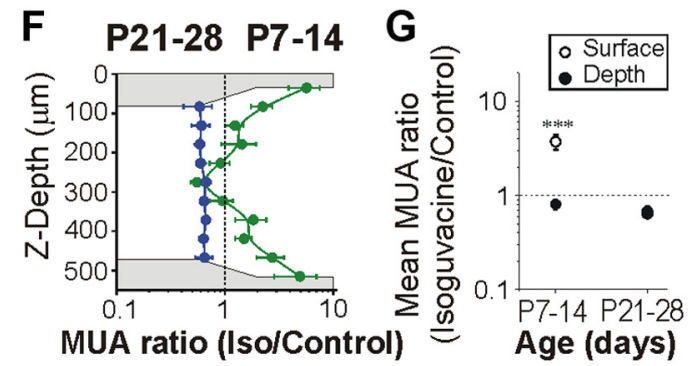

Figure 6. Depth and age-dependent profiles of neuronal chloride concentration and GABA action in acute hippocampal slices. A, B, Overlays of $0-100$ and $100-200 \mu \mathrm{m}$ planes of two-photon fluorescence images of Clomeleon in acute hippocampal slice preparations in vitro of the juvenile (P10) and adult (P28) $\mathrm{CLM}^{-1}$ mice. Neurons pseudo-colored according to resting $\left[\mathrm{Cl}^{-}\right]_{\mathrm{i}}$. $C, D$, Corresponding changes of $\left[\mathrm{Cl}^{-}\right]_{i}$ and the mean $\left[\mathrm{Cl}^{-}\right]_{i}$ as a function of depth at P8 -P14 $(n=6)$ and P21-P28 ( $n=6$ slices). Solid lines represent an exponential function fit to P8 -P14 (green) and sigmoidal (Boltzmann) fit to P21-P28 (blue).E-G, Depth and age profiles of the $G A B A_{A}-R$-mediated signaling in the acute hippocampal slices. $E$, Extracellular field potential recordings from CA3 pyramidal cell layer in the hippocampal slice at P11 using silicone probe at the top and bottom surfaces) and in the middle of slice. Recordings were performed in the presence of $\mathrm{CNQX}$ (10 $\mu \mathrm{M}$ ), $\mathrm{D}$-APV $(40 \mu \mathrm{M})$ and (GP55845 $(2 \mu \mathrm{M})$. Brief application of isoguvacine increased MUA frequency at the surface and inhibits MUA in the middle of slice. $F$, $G$, Summary plot of the depth dependence in the effect of isoguvacine on MUA frequency in two age groups. Shaded area in $\boldsymbol{F}$ corresponds to the MUA-silent zones. Abscissa shows MUA frequency at the peak of isoguvacine effect normalized to the baseline MUA frequency in logarithmic scale (1 signifies no effect). Note that isoguvacine causes excitation at the surfaces and inhibition in the core of slices at P7-P14 ( $n=9$ ) and inhibition at P21-P28 ( $n=8)$.

studies, the net effect of isoguvacine on spontaneous neuronal network-driven activity switched from excitation to inhibition by the end of the second postnatal week (Khazipov et al., 2004; Tyzio et al., 2008). We further examined depth-profile of the $\mathrm{GABA}_{\mathrm{A}}-\mathrm{R}$-mediated effects of isoguvacine in the presence of AMPA, NMDA and $\mathrm{GABA}_{\mathrm{B}}-\mathrm{R}$ antagonists CNQX $(10 \mu \mathrm{M})$, D-APV $(40 \mu \mathrm{M})$ and CGP55812 $(2 \mu \mathrm{M})$ to suppress networkdriven activity (Fig. $6 E$ ). Under these conditions, the effects of isoguvacine on MUA frequency were both age- and depthdependent (Fig. 6F, G). In hippocampal slices from P7-P14 mice $(N=9)$, isoguvacine increased MUA frequency in superficial layers indicating excitatory $\mathrm{GABA}_{\mathrm{A}}-\mathrm{R}$-mediated signaling, but decreased MUA frequency in the inner layers indicating inhibitory $\mathrm{GABA}_{\mathrm{A}}-\mathrm{R}$-mediated signaling (Fig. $6 E-G$ ). In acute hippocampal slices at P21-P28 $(N=8)$, isoguvacine invariably decreased MUA frequency at all depths displaying MUA. Isoguvacine did not elicit MUA in the MUA-silent superficial zones of hippocampal slices at any age. Thus, the effect of the $\mathrm{GABA}_{\mathrm{A}}-\mathrm{R}$ activation by exogenous agonist shows a significant progression from the surface to the core of slices from younger animals, consistent with the progressive change in $\left[\mathrm{Cl}^{-}\right]_{\mathrm{i}}$ with depth and de- gree of neuronal injury in acute hippocampal slices during the second postnatal week (Fig. 6D).

\section{The role of $\mathrm{NKCC} 1$ and $\mathrm{KCC} 2$ cotransporters in acute} post-traumatic neuronal chloride accumulation

$\left[\mathrm{Cl}^{-}\right]_{\mathrm{i}}$ entry into injured neurons is mediated by multiple pathways, including $\mathrm{GABA}_{\mathrm{A}}$ receptor-operated $\mathrm{Cl}^{-}$channels (van den Pol et al., 1996; Hasbani et al., 1998), volume-sensitive $\mathrm{Cl}^{-}$ channels (Inoue and Okada, 2007), as well as the electro-neutral NKCC1 and KCC2 (Pond et al., 2006; Dzhala et al., 2010) which also subserve chloride homeostasis under control conditions (Delpire, 2000; Payne et al., 2003; Gamba, 2005; Blaesse et al., 2009). Trauma induces a significant transient upregulation of NKCC1 protein (Hasbargen et al., 2010) and a concurrent downregulation of KCC2 protein (Nabekura et al., 2002; Bonislawski et al., 2007; Papp et al., 2008). Inhibition of NKCC1 with bumetanide (Isenring et al., 1998; Hannaert et al., 2002) reduces the rate of neuronal chloride accumulation during recurrent seizures in the immature rats and mice (Dzhala et al., 2005, 2010), blocks seizures in the epileptic mirror focus seizures (Khalilov et al., 2003; Nardou et al., 2009, 2011), and reduces seizure activity in 
A

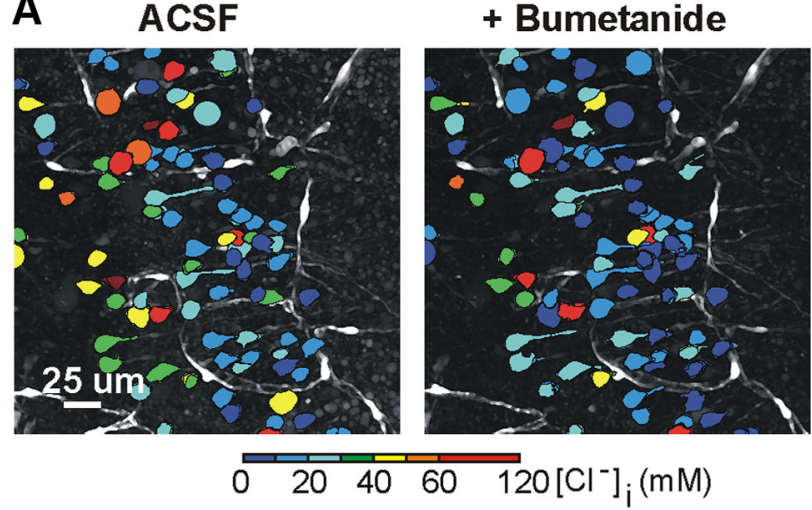

C

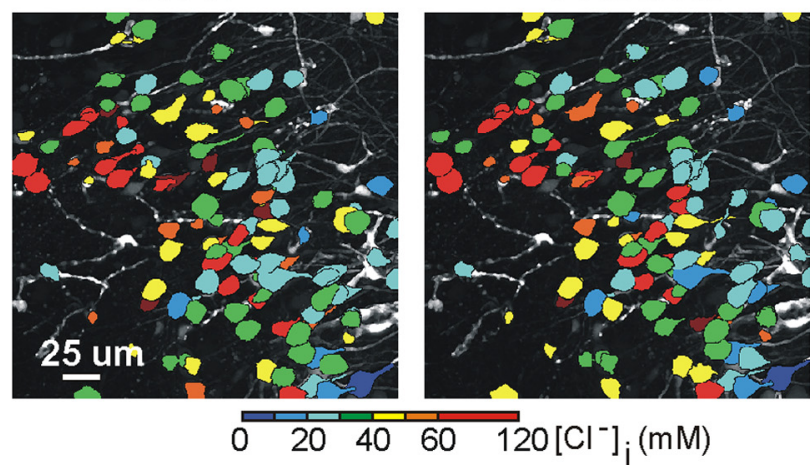

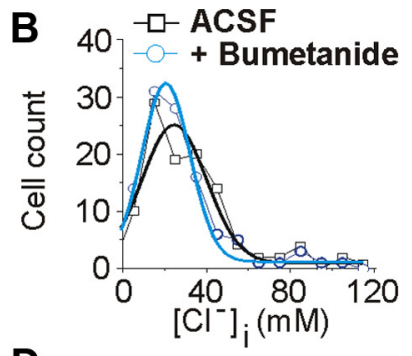
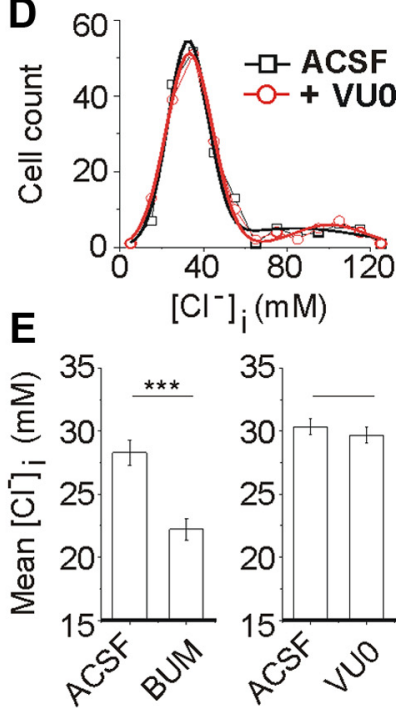

Figure 7. The role of NKCC1 and KCC2 cation-chloride cotransporters in traumatic neuronal chloride accumulation. $\boldsymbol{A}, \boldsymbol{C}$, High-resolution two-photon imaging of Clomeleon in control ACSF (left) and after application of $10 \mu \mathrm{m}$ bumetanide $(\boldsymbol{A})$ and $10 \mu \mathrm{m}$ VU0240551 (C). Imaging was performed in the CA3 region of the acute hippocampal slice preparations at P7. Neurons were pseudo-colored according to resting $\left[\mathrm{Cl}^{-}\right]_{\mathrm{i}}$. Overlays of $0-200 \mu \mathrm{m}$ multiple planes $(2 \mu \mathrm{m}$ step) are shown. $\boldsymbol{B}, \boldsymbol{D}$, Corresponding histograms showing intracellular chloride distribution (bin size $10 \mathrm{~mm}$ ) from the neurons depicted in $\boldsymbol{A}$ and $\boldsymbol{C}$. Solid lines represent Gaussian fit to the data. $\boldsymbol{E}$, The mean $\left[\mathrm{Cl}^{-}\right]_{\mathrm{i}}$ in control and after application of drugs. Mean $\pm \mathbf{S E M}$; ${ }^{*}$ indicates statistically significant difference (Wilcoxon Signed Rank test). Swollen dead cells were excluded from data analysis.

vivo (Brandt et al., 2010). We therefore determined the contribution of NKCC1 and KCC2 transport to trauma-induced chloride accumulation in the acute hippocampal slices.

The effects of the NKCC1 antagonist bumetanide and KCC2 cotransporter antagonist VU0240551 (Delpire et al., 2009) on the $\left[\mathrm{Cl}^{-}\right]_{\mathrm{i}}$ distribution were assessed in acute hippocampal slice preparations from immature P6-P7 CLM-1 mice (Fig. 7A-E). The mean $\left[\mathrm{Cl}^{-}\right]_{\mathrm{i}}$ in the presence of bumetanide (10 $\mu \mathrm{M}$ for $20-30$ min) significantly decreased from $28.3 \pm 1 \mathrm{mM}$ to $22.2 \pm 0.84 \mathrm{mM}$ ( $n=400$ cells in $N=4$ slices; $p<0.0001$, Wilcoxon Signed Rank test; Fig. $7 E$ ). The mean $\left[\mathrm{Cl}^{-}\right]_{\mathrm{i}}$ in the presence of VU0240551 (10 $\mu \mathrm{M}$ for 20-30 min) was not significantly different from control conditions $(30.3 \pm 0.64 \mathrm{mM}$ in control vs $29.7 \pm 0.63 \mathrm{~mm}$ in VU0240551; $n=310$ cells in $N=5$ slices; $p=0.4$; Wilcoxon Signed Rank test; Fig. 7E). Thus, the NKCC1 cotransporter contributes relatively more than KCC2 cotransporter to the steadystate $\left[\mathrm{Cl}^{-}\right]_{\mathrm{i}}$ and post-traumatic increases in $\left[\mathrm{Cl}^{-}\right]_{\mathrm{i}}$ in the acute hippocampal slices at P6-P7, as expected for levels of expression of transporters at this age (Dzhala et al., 2005).

\section{The role of NKCC1 cotransporter in post-traumatic} facilitation of neuronal network activity

The cation-chloride cotransporter NKCC1 promotes networkdriven GDPs and sharp waves in the immature rat hippocampus and neocortex (Dzhala et al., 2005; Sipilä et al., 2006, 2009; Rheims et al., 2008; Nardou et al., 2009). Bumetanide, a selective inhibitor of neuronal $\mathrm{Cl}^{-}$uptake mediated by the NKCC1, reversibly blocks or reduces GDPs and sharp waves in immature hippocampal and neocortical preparations in vitro and in vivo (Dzhala et al., 2005; Sipilä et al., 2006, 2009; Rheims et al., 2008; Nardou et al., 2009; Valeeva et al., 2010). In acute hippocampal slice preparations in vitro from immature rats, synchronous activity (GDPs and sharp waves) is replaced by asynchronous multiple-unit activity which gradually diminishes in the continued presence of bumetanide (Dzhala et al., 2005; Sipilä et al., 2006, 2009; Rheims et al., 2008; Nardou et al., 2009; Valeeva et al., 2010). However, it is not known whether bumetanide exerts these inhibitory effects by reducing $\left[\mathrm{Cl}^{-}\right]_{\mathrm{i}}$ and the consequent excitatory action of GABA in traumatized neurons with accumulated chloride (Figs. 3, 4, 7).

We compared the net effect of activation of $\mathrm{GABA}_{\mathrm{A}}-\mathrm{R}$ by exogenous agonist on multiple-unit activity in the presence of bumetanide in acute hippocampal slices and intact hippocampal preparations in vitro (Fig. 8). Extracellular field potential recordings of population and multiple-unit activity were performed in the CA3 and CA1 pyramidal cell layer $(80-100 \mu \mathrm{m}$ below the surface) in acute hippocampal slice preparations from immature P5-P6 mice (Fig. 8). In line with the previously published data, bath application of bumetanide $(10 \mu \mathrm{M})$ abolished spontaneous network-driven synchronous GDP activity, which was replaced by asynchronous multiple-unit activity $(N=6$ slices; Fig. $8 A$ ) (Dzhala et al., 2005; Sipilä et al., 2006, 2009; Rheims et al., 2008; Nardou et al., 2009; Valeeva et al., 2010). Next, we determined the net effect of activation of $\mathrm{GABA}_{\mathrm{A}}-\mathrm{R}$ by exogenous agonist on multiple-unit activity in the presence of bumetanide. In contrast to the monophasic increase in MUA activity in the absence of 

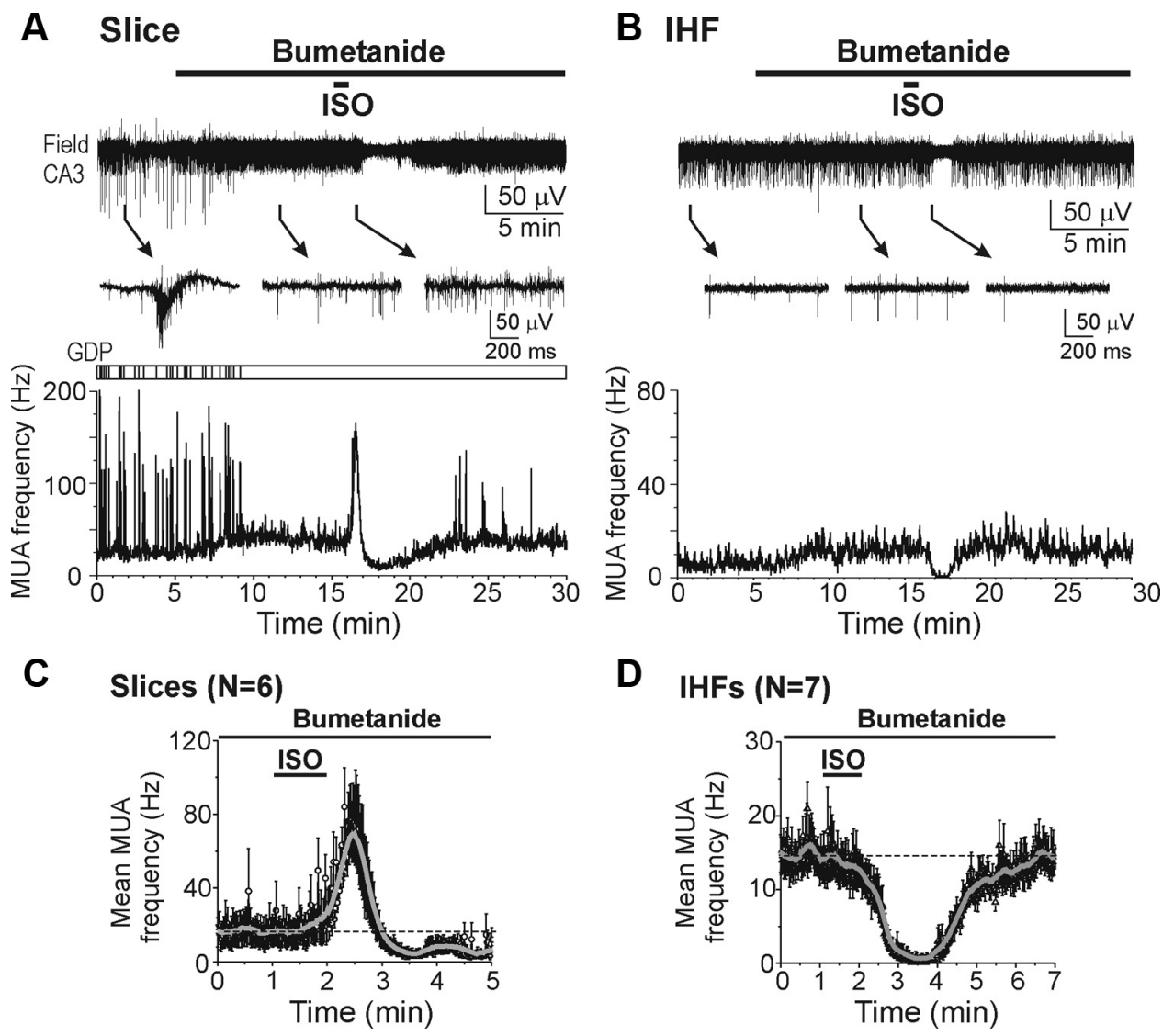

Figure 8. Bumetanide did not prevent excitatory action of GABA on MUA in the hippocampal slices. $A, B$, Extracellular field potential recordings (top traces) and corresponding frequency of MUA (below plots) in the hippocampal slice $(\boldsymbol{A})$ and intact hippocampus $(\boldsymbol{B})$ preparations of the immature P6 CLM-1 mouse. Bumetanide (10 $\mu$ M) application abolished network-driven population bursts (marked by vertical bars). Short-term application of the $G_{A B A}$-A receptor agonist isoguvacine (10 $\mu \mathrm{m}$ for $1 \mathrm{~min}$ ) in presence of bumetanide transiently increased remaining MUA in the hippocampal slice $(\boldsymbol{A})$ and abolished MUA in the intact hippocampus $(\boldsymbol{B})$. $\boldsymbol{C}, \boldsymbol{D}$, Time course of isoguvacine action on MUA frequency in the presence of NKCC1 blocker bumetanide (Mean \pm SEM; $N=6$ hippocampal slices and $N=7$ intact hippocampal preparations from P5-P6 CLM-1 mice. Solid lines represent adjacent averaging of 20 data points. Increased MUA frequency in C indicates that bumetanide did not prevent excitatory action of GABA in the traumatized neurons. Decreased MUA frequency in $\boldsymbol{B}$ indicates inhibitory action of GABA in the intact hippocampal preparation from immature brain.

bumetanide (Fig. 4I), bath application of isoguvacine (10 $\mu \mathrm{M}$ for $1 \mathrm{~min}$ ) in the presence of bumetanide induced a biphasic response, initially increasing MUA frequency from a baseline of $16.7 \pm 8 \mathrm{~Hz}$ to $68 \pm 18 \mathrm{~Hz}$ (mean \pm SEM; $N=6$ slices; $p=$ 0.0008 ; two-sample paired $t$ test; Fig. $8 C$ ) indicating that the initial effect of activation of $\mathrm{GABA}_{\mathrm{A}}-\mathrm{R}$ on neuronal firing activity remained excitatory. Subsequently, isoguvacine reduced MUA frequency to $3.9 \pm 2 \mathrm{~Hz}$ compared with the baseline of $16.7 \pm 8$ $\mathrm{Hz}(p=0.01$; Fig. $8 C)$ indicating a late inhibitory action of GABA in the presence of bumetanide.

In the intact hippocampal preparations in vitro from immature P4-P6 mice, extracellular field potential activity was characterized by multiple-unit activity ( $N=7$ hippocampi) and low-frequency network-driven GDPs (in $N=2$ of seven hippocampi). Similar to acute hippocampal slices (Fig. $8 \mathrm{~A}$ ), bath application of bumetanide (10 $\mu \mathrm{M}$ for $10 \mathrm{~min}$ ) abolished GDPs and this was replaced by asynchronous multiple-unit activity (Fig. $8 B$ ). In contrast to acute hippocampal slices, in the intact hippocampal preparations in vitro bath application of isoguvacine ( $10 \mu \mathrm{M}$ for $1 \mathrm{~min})$ in the presence of bumetanide, induced a monophasic reduction of MUA frequency from $14.7 \pm 1.9 \mathrm{~Hz}$ to $1.2 \pm 0.7 \mathrm{~Hz}$ (mean $\pm \mathrm{SEM} ; N=$ 7 hippocampi; $p=0.0002$; two-sample paired $t$ test; Fig. $8 D$ ) indicating that the net effect of activation of $\mathrm{GABA}_{\mathrm{A}}-\mathrm{R}$ on neuronal firing activity was inhibitory, as it was in the absence of bumetanide (Fig. 4H). Thus, NKCC1 activity strongly contrib- uted to the intracellular chloride accumulation and facilitation of network activity associated with the widespread neural shear injury induced during preparation of acute brain slices. Bumetanide reduced the rate of post-traumatic accumulation of $\left[\mathrm{Cl}^{-}\right]_{\mathrm{i}}$ and the net effect of excitatory GABA responses on neuronal network activity (Figs. 7, 8). However, as might be predicted from the effect on $\left[\mathrm{Cl}^{-}\right]_{\mathrm{i}}$ (Fig. $7 \mathrm{~B}, E$ ), the bumetanide-induced negative shift if $E_{\mathrm{GABA}}$ was not sufficient to prevent all excitatory $\mathrm{GABA}_{\mathrm{A}}$-receptor-mediated signaling in traumatized neurons, and some other acute mechanisms contribute to the positive shift in $E_{\mathrm{GABA}}$ and isoguvacine-induced increases in MUA frequency (Figs. 7E, 8C).

\section{Effects of neuroprotective strategies during hippocampal slice preparation}

We addressed the impact of brain slicing on the neuronal damage profile and neuronal $\left[\mathrm{Cl}^{-}\right]_{\mathrm{i}}$ throughout the hippocampal slice preparation in regular ACSF (solution 1) vs preparation in a solution containing $100 \mu \mathrm{M}$ bumetanide (solution 2) to block NKCC1 and KCC2 activity or vs a putatively neuroprotective solution in which sucrose replaced sodium, calcium was reduced and magnesium increased (solution 3, see Materials and Methods) (Fig. 9). In three groups of hippocampal slices prepared from P5-P7 CLM-1 mice, the cell volume and $\left[\mathrm{Cl}^{-}\right]_{\mathrm{i}}$ progressively decreased as a function of depth (Fig. 9C,D). The most 
A ACSF+Bumetanide B
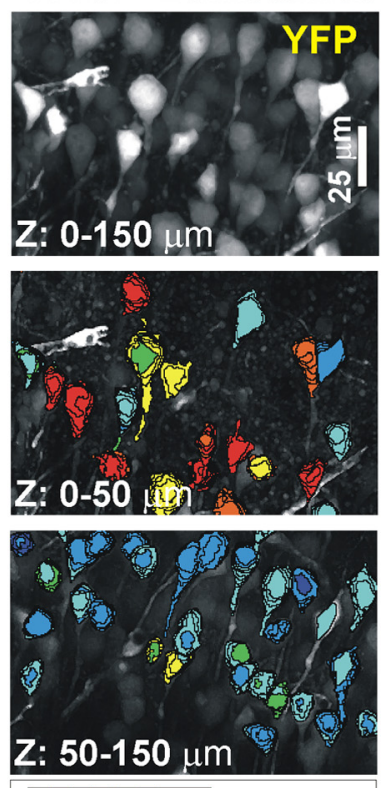

$\left.\begin{array}{lllllll}0 & 20 & 40 & 60 & 120 & {\left[\mathrm{Cl}^{-}\right.}\end{array}\right]_{\mathrm{i}}(\mathrm{mM})$
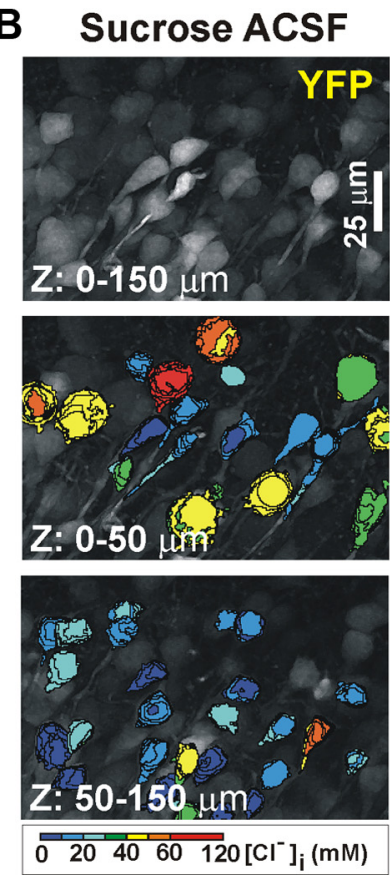

C

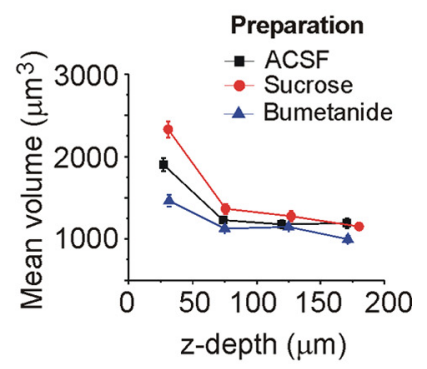

D

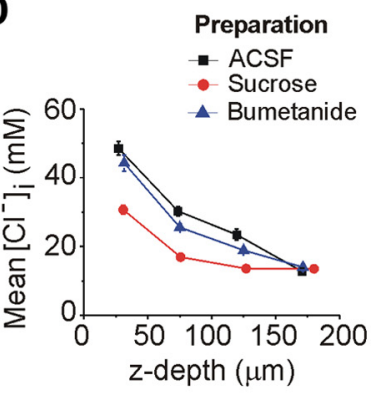

Figure 9. The effects of slicing conditions on neuronal viability and intracellular chloride. $\boldsymbol{A}, \boldsymbol{B}$, Hippocampal slices were prepared in ACSF containing $100 \mu \mathrm{m}$ bumetanide $(\boldsymbol{A})$ and in a high-sucrose solution (B; see Materials and Methods). YFP expression (0-150 $\mu \mathrm{m}$; top) and intracellular chloride concentration in the CA1 region of the acute hippocampal slices at P6. 0verlays of $0-50$ and 50-150 $\mu$ m multiple planes are shown. $C, D$, The mean cell volume and $\left[C^{-}\right]_{i}$ (mean $\left.\pm S E M\right)$ as a function of depth in the hippocampal slices prepared in control $A C S F(n=6$; black), in the presence of bumetanide ( $n=4$; blue), and in a high-sucrose solution ( $n=6$ slices; red). Slices were prepared from P5-P7 CLM-1 mice.

injured superficial layers $(0-50 \mu \mathrm{m})$ of hippocampal slices from all three groups were characterized by significantly larger cell volume and higher $\left[\mathrm{Cl}^{-}\right]_{\mathrm{i}}$, suggesting a similar distribution of neuronal damage in hippocampal slices prepared under different experimental conditions. In the intermediate layers (50-150 $\mu \mathrm{m})$, the mean cell volume was not significantly different between all three group of slices (Fig. 9C), however the mean $\left[\mathrm{Cl}^{-}\right]_{\mathrm{i}}$ in acute hippocampal slices prepared in ACSF $(27.9 \pm 1.1 \mathrm{~mm}$, $n=229$ cells imaged at this depth out of 423 cells imaged at all depths in 6 slices) was significantly higher than in slices prepared in the presence of bumetanide $(23.4 \pm 0.6 \mathrm{~mm}, n=179$ of 266 cells in 4 slices; $p=0.01$, Mann-Whitney test; Fig. 9D) or in a high-sucrose solution $(15.5 \pm 0.46 \mathrm{~mm}, n=258$ of 495 imaged cells in 6 slices; $p<0.001$; Fig. 9D). In contrast, the mean cell volume and $\left[\mathrm{Cl}^{-}\right]_{\mathrm{i}}$ in the deepest morphologically preserved layer (150-200 $\mu \mathrm{m})$ was not significantly different between all three group of slices (Fig. 9C,D). Thus, blocking cation-chloride cotransport with the diuretic bumetanide reduced neuronal volume and trauma-induced neuronal chloride accumulation (Fig. $9 C, D)$. Reducing extracellular chloride in high-sucrose solution during hippocampal slice preparation did not prevent neuronal swelling but produced the most significant reduction in traumainduced neuronal chloride accumulation, confirming extracellular chloride as the source of increased neuronal $\left[\mathrm{Cl}^{-}\right]_{\mathrm{i}}$.

\section{Discussion}

Trauma-induced neuronal chloride accumulation alters network activity

These results indicate that acute shear injury of neuronal processes is associated with increased neuronal $\left[\mathrm{Cl}^{-}\right]_{\mathrm{i}}$ that is evident at sites distant from the shear injury including the soma. Although many neurons with increased intracellular chloride exhibit morphological features of cell death, many others do not. Network-wide assays of GABA function clearly indicate that many neurons with excitatory responses to GABA are still synaptically functional, particularly in slices prepared from young animals. In the developing hippocampus, these neurons shift the net network-wide effect of GABA from inhibition to excitation after trauma (Figs. 4, 6). Clinically, the profound post-traumatic change in the polarity of the GABA response may be a significant pathophysiological mechanism underlying acute post-traumatic seizures (Kahle et al., 2008).

The persistent action potential activity in the most damaged areas of young but not older slices provides a mechanism by which excitatory actions of GABA in traumatized neurons can contribute to seizure activity in the developing brain. This may underlie the increased of seizure activity in the immediate posttraumatic period in children under age 2 (Gilles and Nelson, 1998; Liesemer et al., 2011). The preserved capacity to generate action potentials after injury may also underlie the high incidence of seizures in the immature brain after hypoxic-ischemic injury (Sarnat and Sarnat, 1976; Wusthoff et al., 2011), despite the fact that substantial post-hypoxic increases in $\left[\mathrm{Cl}^{-}\right]_{\mathrm{i}}$ are also observed in mature neurons (Pond et al., 2006). These interesting correlations point to future studies testing whether the preserved action potential activity in damaged areas arises from damaged neurons and is accompanied by transmitter release. The mechanisms of preservation are likely to be interesting as well. Injuries induce death at different rates and by different mechanisms in developing vs mature neurons, and the preserved signaling in the damaged regions of the developing slices may reflect these differences (Bittigau et al., 1999; Lado et al., 2002).

Diuretics had modest effects on $\left[\mathrm{Cl}^{-}\right]_{\mathrm{i}}$ accumulation and action potential responses to GABA, but more significant impact on network-wide synchronous activity, consistent with the nonlinear effects of modulation of neuronal excitability on the output of networks of neurons (Glykys and Mody, 2006; Grashow et al., 
2010). Thus diuretics might be of utility in the prevention of early seizures, particularly electrographic seizure that do not respond to standard anticonvulsant prophylaxis (Claassen et al., 2004; Glykys et al., 2009).

\section{Are the excitatory effects of GABA in preparations of the developing nervous system a consequence of trauma artifact?} Traumatic shifts in $\left[\mathrm{Cl}^{-}\right]_{\mathrm{i}}$ and $E_{\mathrm{GABA}}$ may complicate slice studies of network effects of GABA in experimental preparations of the developing brain (Cherubini et al., 1991; Bonifazi et al., 2009; Glykys et al., 2009). It has frequently been noted that GABA has dual actions in the developing brain, with evidence for both inhibitory and excitatory effects (Khalilov et al., 1999; Valeeva et al., 2010). Although carbohydrate vs ketone carbon sources have been proposed as an important determinant of $E_{\mathrm{GABA}}$ (Rheims et al., 2009), a more parsimonious explanation is that the observed changes in $E_{\mathrm{GABA}}$ are a consequence of $\mathrm{HCO}_{3}^{-}-\mathrm{Cl}^{-}$exchange in response to the intracellular $\mathrm{pH}$ shifts induced by the experimental protocol (see discussion in Glykys et al., 2009; Tyzio et al., 2011). The present data suggest that the duality of GABA effects is due in part to the bimodal distribution of $\left[\mathrm{Cl}^{-}\right]_{\mathrm{i}}$ in neurons in the slice preparation. Superficial neurons are more damaged, have higher $\left[\mathrm{Cl}^{-}\right]_{\mathrm{i}}$, and exhibit excitatory responses to GABA, while deeper neurons are less damaged, have lower $\left[\mathrm{Cl}^{-}\right]_{\mathrm{i}}$, and exhibit inhibitory responses to GABA. In contrast, in the intact hippocampal preparation from immature mice (P6-P7) the effect of $\mathrm{GABA}_{\mathrm{A}} \mathrm{R}$ activation is predominantly inhibitory, the mean $\left[\mathrm{Cl}^{-}\right]_{\mathrm{i}}$ is lower overall, $\left[\mathrm{Cl}^{-}\right]_{\mathrm{i}}$ varies less with depth, and $\left[\mathrm{Cl}^{-}\right]_{\mathrm{i}}$ is lowest at the surface of the preparation (Fig. 4). The increase in $\left[\mathrm{Cl}^{-}\right]_{\mathrm{i}}$ with depth may be result of a limited oxygen supply to the deeper neurons (Inglefield and Schwartz-Bloom, 1998; Galeffi et al., 2004; Pond et al., 2006) and is the major limitation on the use of intact preparations from animals older than P8.

Correlated bursts of polysynaptic glutamate and GABAmediated network-driven activity have been observed in the immature rat in vivo (Leinekugel et al., 2002; Katz and Shatz, 1996; Sipilä et al., 2006) and in the intact hippocampal preparation in vitro (Leinekugel et al., 1998) (Fig. 4E). Traumatic increases in neuronal $\left[\mathrm{Cl}^{-}\right]_{\mathrm{i}}$ and $E_{\mathrm{GABA}}$ accentuate a physiological distribution of neuronal $\left[\mathrm{Cl}^{-}{ }_{\mathrm{i}}\right]$ that is already broad (Fig. $4 \mathrm{C}$ ). The increased prevalence of excitatory network activity in the slice vs intact preparation underlines the importance of excitatory GABAergic signaling in the genesis of these network events. This role of GABA is important both physiologically (Ben-Ari et al., 2007) and pathologically (Kahle et al., 2008; Dzhala et al., 2010). Physiological rates of neuronal $\mathrm{Cl}^{-}$uptake are important for synaptogenesis (Ge et al., 2006; Cancedda et al., 2007; Wang et al., 2008). Pathologically, immature seizures commonly occur after neuronal injury (Wusthoff et al., 2011), respond poorly to GABAergic anticonvulsants electro-graphically (Scher et al., 2003; Murray et al., 2008), but do respond to inhibitors of neuronal $\mathrm{Cl}^{-}$uptake, either alone (Dzhala et al., 2005) or in combination with GABAergic anticonvulsants (Dzhala et al., 2008, 2010; Nardou et al., 2009).

Neurons in the outer $100 \mu \mathrm{m}$ of mature hippocampal slices with elevated $\left[\mathrm{Cl}^{-}\right]_{\mathrm{i}}$ (Figs. 5, 6) are frequently targeted in patch-clamp studies. Thus it may be that traumatized neurons are disproportionately represented in electrophysiological studies reporting depolarizing GABA responses in adult neurons (Gulledge and Stuart, 2003). However, the neurons in the most superficial $100 \mu \mathrm{m}$ of the slice did not contribute to the network-wide effect of exogenous GABA in the mature preparations, which remained inhibitory (Figs. $5 F, G$, $6 F, G$ ). This may be a consequence of the lower ratio of neurons with elevated vs physiological $\left[\mathrm{Cl}^{-}\right]_{\mathrm{i}}$ in mature vs developing preparations. Alternatively it may reflect reduced efferent and afferent synaptic activity in injured mature neurons, and this could underlie the age dependence of early traumatic seizures (Liesemer et al., 2011). We did not systematically investigate the increase in $\left[\mathrm{Cl}^{-}\right]_{\mathrm{i}}$ as a function of time after slice preparation; the data reported here were gathered $1-3 \mathrm{~h}$ after slicing. The number of neurons with elevated $\left[\mathrm{Cl}^{-}\right]_{i}$ continued to increase for $24 \mathrm{~h}$ in cultured neurons subjected to trauma (van den Pol et al., 1996), and it is commonly accepted that hyperexcitability and frankly epileptic activity are signs that slices have become "too old" and should be discarded. Thus late deteriorations in slice physiology may reflect changes in $\mathrm{GABA}_{\mathrm{A}}-\mathrm{R}$ signaling triggered by progressive post-traumatic increases in $\left[\mathrm{Cl}^{-}\right]_{\mathrm{i}}$.

\section{Post-traumatic neuronal chloride transport and volume regulation}

The mechanisms of neuronal swelling following trauma are not known. Acute changes in transporter expression have been demonstrated (Nabekura et al., 2002; Bonislawski et al., 2007; Papp et al., 2008; Hasbargen et al., 2010), but other changes including damage to the axonal cytoskeletal elements and secondary changes in dendrites (Monnerie et al., 2010) have also been observed. Traumatic cytoskeletal injury and loss of cytoplasm may trigger volume-sensitive apoptotic mechanisms (Maeno et al., 2000 ), so neurons must replace the lost volume or die. The only available replacement is extracellular fluid containing $110 \mathrm{~mm}$ chloride, so neurons may have no choice but to increase chloride as a consequence of importing isotonic extracellular fluid immediately following trauma. The increase in volume without increase in $\left[\mathrm{Cl}^{-}\right]_{\mathrm{i}}$ in low-chloride slicing solutions (Fig. 9C,D) and the significant though modest effects of cation-chloride transport inhibition (Fig. 7) suggest that dysregulation of cation-chloride cotransport is only one part of a more complex post-traumatic volume dysregulation. Cation-chloride cotransporters NKCC1 and KCC2 differently contribute to the post-traumatic increase in neuronal $\left[\mathrm{Cl}^{-}\right]_{\mathrm{i}}$ (Fig. 7). The larger role of NKCC1 vs KCC2 in chloride accumulation in the developing hippocampus is consistent with its higher level of expression in developing neurons (Plotkin et al., 1997; Dzhala et al., 2005). Although NKCC1 typically mediates chloride accumulation and cytoplasmic volume increases, while KCC2 mediates chloride extrusion and volume decreases, both transporters can run in reverse (Thompson and Gähwiler, 1989; Brumback and Staley, 2008; Hoffmann et al., 2009).

While techniques for preparing brain slices vary to some extent between laboratories, we propose that it is the number, diameter, and proximity to the soma of acutely transected dendrites and axons, rather than the technique with which they are transected, that determines the increase in neuronal $\left[\mathrm{Cl}^{-}\right]_{\mathrm{i}}$. However, this does not exclude reductions in traumatic $\left[\mathrm{Cl}^{-}\right]_{\mathrm{i}}$ with new techniques (Fig. 9). New techniques for reductions in traumatic $\left[\mathrm{Cl}^{-}\right]_{\mathrm{i}}$ in vitro could also form the basis for important new strategies to treat post-traumatic edema and seizures.

\section{References}

Bak IJ, Misgeld U, Weiler M, Morgan E (1980) The preservation of nerve cells in rat neostriatal slices maintained in vitro: a morphological study. Brain Res 197:341-353.

Ben-Ari Y (1987) Brain damage caused by seizure activity. Electroencephalogr Clin Neurophysiol Suppl 39:209-211.

Ben-Ari Y, Cherubini E, Corradetti R, Gaiarsa JL (1989) Giant synaptic potentials in immature rat CA3 hippocampal neurones. J Physiol 416:303-325. 
Ben-Ari Y, Gaiarsa JL, Tyzio R, Khazipov R (2007) GABA: a pioneer transmitter that excites immature neurons and generates primitive oscillations. Physiol Rev 87:1215-1284.

Berglund K, Schleich W, Wang H, Feng G, Hall WC, Kuner T, Augustine GJ (2008) Imaging synaptic inhibition throughout the brain via genetically targeted Clomeleon. Brain Cell Biol 36:101-118.

Bittigau P, Sifringer M, Pohl D, Stadthaus D, Ishimaru M, Shimizu H, Ikeda M, Lang D, Speer A, Olney JW, Ikonomidou C (1999) Apoptotic neurodegeneration following trauma is markedly enhanced in the immature brain. Ann Neurol 45:724-735.

Blaesse P, Airaksinen MS, Rivera C, Kaila K (2009) Cation-chloride cotransporters and neuronal function. Neuron 61:820-838.

Bonifazi P, Goldin M, Picardo MA, Jorquera I, Cattani A, Bianconi G, Represa A, Ben-Ari Y, Cossart R (2009) GABAergic hub neurons orchestrate synchrony in developing hippocampal networks. Science 326:1419-1424.

Bonislawski DP, Schwarzbach EP, Cohen AS (2007) Brain injury impairs dentate gyrus inhibitory efficacy. Neurobiol Dis 25:163-169.

Brandt C, Nozadze M, Heuchert N, Rattka M, Löscher W (2010) Diseasemodifying effects of phenobarbital and the NKCC1 inhibitor bumetanide in the pilocarpine model of temporal lobe epilepsy. J Neurosci 30:8602-8612.

Brumback AC, Staley KJ (2008) Thermodynamic regulation of NKCC1mediated $\mathrm{Cl}^{-}$cotransport underlies plasticity of $\mathrm{GABA}(\mathrm{A})$ signaling in neonatal neurons. J Neurosci 28:1301-1312.

Cancedda L, Fiumelli H, Chen K, Poo MM (2007) Excitatory GABA action is essential for morphological maturation of cortical neurons in vivo. J Neurosci 27:5224-5235.

Cherubini E, Gaiarsa JL, Ben-Ari Y (1991) GABA: an excitatory transmitter in early postnatal life. Trends Neurosci 14:515-519.

Chiaretti A, Piastra M, Pulitanò S, Pietrini D, De Rosa G, Barbaro R, Di Rocco C (2002) Prognostic factors and outcome of children with severe head injury: an 8-year experience. Childs Nerv Syst 18:129-136.

Claassen J, Mayer SA, Kowalski RG, Emerson RG, Hirsch LJ (2004) Detection of electrographic seizures with continuous EEG monitoring in critically ill patients. Neurology 62:1743-1748.

Cohen I, Miles R (2000) Contributions of intrinsic and synaptic activities to the generation of neuronal discharges in in vitro hippocampus. J Physiol 524:485-502.

Cohen I, Navarro V, Clemenceau S, Baulac M, Miles R (2002) On the origin of interictal activity in human temporal lobe epilepsy in vitro. Science 298:1418-1421.

Darzynkiewicz Z, Pozarowski P, Lee BW, Johnson GL (2011) Fluorochromelabeled inhibitors of caspases: convenient in vitro and in vivo markers of apoptotic cells for cytometric analysis. Methods Mol Biol 682:103-114.

Davies ML, Kirov SA, Andrew RD (2007) Whole isolated neocortical and hippocampal preparations and their use in imaging studies. J Neurosci Methods 166:203-216.

Delpire E (2000) Cation-chloride cotransporters in neuronal communication. News Physiol Sci 15:309-312.

Delpire E, Days E, Lewis LM, Mi D, Kim K, Lindsley CW, Weaver CD (2009) Small-molecule screen identifies inhibitors of the neuronal K-Cl cotransporter KCC2. Proc Natl Acad Sci U S A 106:5383-5388.

Duebel J, Haverkamp S, Schleich W, Feng G, Augustine GJ, Kuner T, Euler T (2006) Two-photon imaging reveals somatodendritic chloride gradient in retinal ON-type bipolar cells expressing the biosensor Clomeleon. Neuron 49:81-94.

Dzhala VI, Staley KJ (2003) Excitatory actions of endogenously released GABA contribute to initiation of ictal epileptiform activity in the developing hippocampus. J Neurosci 23:1840-1846.

Dzhala VI, Talos DM, Sdrulla DA, Brumback AC, Mathews GC, Benke TA, Delpire E, Jensen FE, Staley KJ (2005) NKCC1 transporter facilitates seizures in the developing brain. Nat Med 11:1205-1213.

Dzhala VI, Brumback AC, Staley KJ (2008) Bumetanide enhances phenobarbital efficacy in a neonatal seizure model. Ann Neurol 63:222-235.

Dzhala VI, Kuchibhotla KV, Glykys JC, Kahle KT, Swiercz WB, Feng G, Kuner T, Augustine GJ, Bacskai BJ, Staley KJ (2010) Progressive NKCC1dependent neuronal chloride accumulation during neonatal seizures. J Neurosci 30:11745-11761.

Ebihara S, Shirato K, Harata N, Akaike N (1995) Gramicidin-perforated patch recording: GABA response in mammalian neurones with intact intracellular chloride. J Physiol 484:77-86.

Galeffi F, Sah R, Pond BB, George A, Schwartz-Bloom RD (2004) Changes in intracellular chloride after oxygen-glucose deprivation of the adult hippocampal slice: effect of diazepam. J Neurosci 24:4478-4488.

Gamba G (2005) Molecular physiology and pathophysiology of electroneutral cation-chloride cotransporters. Physiol Rev 85:423-493.

Ge S, Goh ELK, Sailor KA, Kitabatake Y, Ming GL, Song H (2006) GABA regulates synaptic integration of newly generated neurons in the adult brain. Nature 439:589-593.

Gilles EE, Nelson MD Jr (1998) Cerebral complications of nonaccidental head injury in childhood. Pediatr Neurol 19:119-128.

Glickfeld LL, Roberts JD, Somogyi P, Scanziani M (2009) Interneurons hyperpolarize pyramidal cells along their entire somatodendritic axis. Nat Neurosci 12:21-23.

Glykys J, Mody I (2006) Hippocampal network hyperactivity after selective reduction of tonic inhibition in GABA A receptor alpha5 subunitdeficient mice. J Neurophysiol 95:2796-2807.

Glykys J, Dzhala VI, Kuchibhotla KV, Feng G, Kuner T, Augustine G, Bacskai BJ, Staley KJ (2009) Differences in cortical versus subcortical GABAergic signaling: a candidate mechanism of electroclinical uncoupling of neonatal seizures. Neuron 63:657-672.

Grashow R, Brookings T, Marder E (2010) Compensation for variable intrinsic neuronal excitability by circuit-synaptic interactions. J Neurosci 30:9145-9156.

Gulledge AT, Stuart GJ (2003) Excitatory actions of GABA in the cortex. Neuron 37:299-309.

Hannaert P, Alvarez-Guerra M, Pirot D, Nazaret C, Garay RP (2002) Rat NKCC2/NKCC1 cotransporter selectivity for loop diuretic drugs. Naunyn Schmiedebergs Arch Pharmacol 365:193-199.

Hasbani MJ, Hyrc KL, Faddis BT, Romano C, Goldberg MP (1998) Distinct roles for sodium, chloride, and calcium in excitotoxic dendritic injury and recovery. Exp Neurol 154:241-258

Hasbargen T, Ahmed MM, Miranpuri G, Li L, Kahle KT, Resnick D, Sun D (2010) Role of NKCC1 and KCC2 in the development of chronic neuropathic pain following spinal cord injury. Ann N Y Acad Sci 1198:168-172.

Hoffmann EK, Lambert IH, Pedersen SF (2009) Physiology of cell volume regulation in vertebrates. Physiol Rev 89:193-277.

Inglefield JR, Schwartz-Bloom RD (1998) Optical imaging of hippocampal neurons with a chloride-sensitive dye: early effects of in vitro ischemia. J Neurochem 70:2500-2509.

Inoue H, Okada Y (2007) Roles of volume-sensitive chloride channel in excitotoxic neuronal injury. J Neurosci 27:1445-1455.

Isenring P, Jacoby SC, Payne JA, Forbush B 3rd (1998) Comparison of Na$\mathrm{K}-\mathrm{Cl}$ cotransporters. NKCC1, NKCC2, and the HEK cell Na-L-Cl cotransporter. J Biol Chem 273:11295-11301.

Kahle KT, Staley KJ, Nahed BV, Gamba G, Hebert SC, Lifton RP, Mount DB (2008) Roles of the cation-chloride cotransporters in neurological disease. Nat Clin Pract Neurol 4:490-503.

Katz LC, Shatz CJ (1996) Synaptic activity and the construction of cortical circuits. Science 274:1133-1138.

Keenan HT, Hooper SR, Wetherington CE, Nocera M, Runyan DK (2007) Neurodevelopmental consequences of early traumatic brain injury in 3-year-old children. Pediatrics 119:e616-e623.

Khalilov I, Esclapez M, Medina I, Aggoun D, Lamsa K, Leinekugel X, Khazipov R, Ben-Ari Y (1997) A novel in vitro preparation: the intact hippocampal formation. Neuron 19:743-749.

Khalilov I, Dzhala V, Ben-Ari Y, Khazipov R (1999) Dual role of GABA in the neonatal rat hippocampus. Dev Neurosci 21:310-319.

Khalilov I, Holmes GL, Ben-Ari Y (2003) In vitro formation of a secondary epileptogenic mirror focus by interhippocampal propagation of seizures. Nat Neurosci 6:1079-1085.

Khazipov R, Khalilov I, Tyzio R, Morozova E, Ben-Ari Y, Holmes GL (2004) Developmental changes in GABAergic actions and seizure susceptibility in the rat hippocampus. Eur J Neurosci 19:590-600.

Kirov SA, Sorra KE, Harris KM (1999) Slices have more synapses than perfusion-fixed hippocampus from both young and mature rats. J Neurosci 19:2876-2886.

Koch C, Poggio T, Torre V (1983) Nonlinear interactions in a dendritic tree: localization, timing, and role in information processing. Proc Natl Acad Sci U S A 80:2799-2802.

Kuner T, Augustine GJ (2000) A genetically encoded ratiometric indicator for chloride: capturing chloride transients in cultured hippocampal neurons. Neuron 27:447-459. 
Lado FA, Laureta EC, Moshé SL (2002) Seizure-induced hippocampal damage in the mature and immature brain. Epileptic Disord 4:83-97.

Lee BW, Olin MR, Johnson GL, Griffin RJ (2008) In vitro and in vivo apoptosis detection using membrane permeant fluorescent-labeled inhibitors of caspases. Methods Mol Biol 414:109-135.

Leinekugel X, Medina I, Khalilov I, Ben-Ari Y, Khazipov R (1997) $\mathrm{Ca}^{2+}$ oscillations mediated by the synergistic excitatory actions of GABA(A) and NMDA receptors in the neonatal hippocampus. Neuron 18:243-255.

Leinekugel X, Khalilov I, Ben-Ari Y, Khazipov R (1998) Giant depolarizing potentials: the septal pole of the hippocampus paces the activity of the developing intact septohippocampal complex in vitro. J Neurosci 18:6349-6357.

Leinekugel X, Khazipov R, Cannon R, Hirase H, Ben-Ari Y, Buzsáki G (2002) Correlated bursts of activity in the neonatal hippocampus in vivo. Science 296:2049-2052.

Liesemer K, Bratton SL, Zebrack CM, Brockmeyer D, Statler KD (2011) Early post-traumatic seizures in moderate to severe pediatric traumatic brain injury: rates, risk factors, and clinical features. J Neurotrauma 28:755-762.

Maeno E, Ishizaki Y, Kanaseki T, Hazama A, Okada Y (2000) Normotonic cell shrinkage because of disordered volume regulation is an early prerequisite to apoptosis. Proc Natl Acad Sci U S A 97:9487-9492.

Mazarati A, Shin D, Sankar R (2009) Bumetanide inhibits rapid kindling in neonatal rats. Epilepsia 50:2117-2122.

Monnerie H, Tang-Schomer MD, Iwata A, Smith DH, Kim HA, Le Roux PD (2010) Dendritic alterations after dynamic axonal stretch injury in vitro. Exp Neurol 224:415-423

Murray DM, Boylan GB, Ali I, Ryan CA, Murphy BP, Connolly S (2008) Defining the gap between electrographic seizure burden, clinical expression and staff recognition of neonatal seizures. Arch Dis Child Fetal Neonatal Ed 93:F187-F191.

Nabekura J, Ueno T, Okabe A, Furuta A, Iwaki T, Shimizu-Okabe C, Fukuda A, Akaike N (2002) Reduction of KCC2 expression and GABAA receptor-mediated excitation after in vivo axonal injury. J Neurosci 22:4412-4417.

Nardou R, Ben-Ari Y, Khalilov I (2009) Bumetanide, an NKCC1 antagonist, does not prevent formation of epileptogenic focus but blocks epileptic focus seizures in immature rat hippocampus. J Neurophysiol 101: $2878-2888$.

Nardou R, Yamamoto S, Chazal G, Bhar A, Ferrand N, Dulac O, Ben-Ari Y, Khalilov I (2011) Neuronal chloride accumulation and excitatory GABA underlie aggravation of neonatal epileptiform activities by phenobarbital. Brain 134:987-1002.

Papp E, Rivera C, Kaila K, Freund TF (2008) Relationship between neuronal vulnerability and potassium-chloride cotransporter 2 immunoreactivity in hippocampus following transient forebrain ischemia. Neuroscience 154:677-689.

Payne JA, Rivera C, Voipio J, Kaila K (2003) Cation-chloride co-transporters in neuronal communication, development and trauma. Trends Neurosci 26:199-206.

Plotkin MD, Snyder EY, Hebert SC, Delpire E (1997) Expression of the $\mathrm{Na}-\mathrm{K}-2 \mathrm{Cl}$ cotransporter is developmentally regulated in postnatal rat brains: a possible mechanism underlying GABA's excitatory role in immature brain. J Neurobiol 33:781-795.

Pond BB, Berglund K, Kuner T, Feng G, Augustine GJ, Schwartz-Bloom RD (2006) The chloride transporter $\mathrm{Na}(+)-\mathrm{K}(+)-\mathrm{Cl}(-)$ cotransporter isoform- 1 contributes to intracellular chloride increases after in vitro ischemia. J Neurosci 26:1396-1406.

Rheims S, Minlebaev M, Ivanov A, Represa A, Khazipov R, Holmes GL, Ben-Ari Y, Zilberter Y (2008) Excitatory GABA in rodent developing neocortex in vitro. J Neurophysiol 100:609-619.

Rheims S, Holmgren CD, Chazal G, Mulder J, Harkany T, Zilberter T, Zilberter Y
(2009) GABA action in immature neocortical neurons directly depends on the availability of ketone bodies. J Neurochem 110:1330-1338.

Rothman SM (1985) The neurotoxicity of excitatory amino acids is produced by passive chloride influx. J Neurosci 5:1483-1489.

Sarnat HB, Sarnat MS (1976) Neonatal encephalopathy following fetal distress. A clinical and electroencephalographic study. Arch Neurol 33:696-705.

Scher MS, Alvin J, Gaus L, Minnigh B, Painter MJ (2003) Uncoupling of EEG-clinical neonatal seizures after antiepileptic drug use. Pediatr Neurol 28:277-280

Sipilä ST, Huttu K, Soltesz I, Voipio J, Kaila K (2005) Depolarizing GABA acts on intrinsically bursting pyramidal neurons to drive giant depolarizing potentials in the immature hippocampus. J Neurosci 25:5280-5289.

Sipilä ST, Schuchmann S, Voipio J, Yamada J, Kaila K (2006) The cationchloride cotransporter NKCC1 promotes sharp waves in the neonatal rat hippocampus. J Physiol 573:765-773.

Sipilä ST, Huttu K, Yamada J, Afzalov R, Voipio J, Blaesse P, Kaila K (2009) Compensatory enhancement of intrinsic spiking upon NKCC1 disruption in neonatal hippocampus. J Neurosci 29:6982-6988.

Staley KJ, Mody I (1992) Shunting of excitatory input to dentate gyrus granule cells by a depolarizing GABAA receptor-mediated postsynaptic conductance. J Neurophysiol 68:197-212.

Thompson SM, Gähwiler BH (1989) Activity-dependent disinhibition. II. Effects of extracellular potassium, furosemide, and membrane potential on ECl- in hippocampal CA3 neurons. J Neurophysiol 61:512-523.

Tsourkas A, Newton G, Perez JM, Basilion JP, Weissleder R (2005) Detection of peroxidase/H2O2-mediated oxidation with enhanced yellow fluorescent protein. Anal Chem 77:2862-2867.

Tyzio R, Ivanov A, Bernard C, Holmes GL, Ben-Ari Y, Khazipov R (2003) Membrane potential of CA3 hippocampal pyramidal cells during postnatal development. J Neurophysiol 90:2964-2972.

Tyzio R, Holmes GL, Ben-Ari Y, Khazipov R (2007) Timing of the developmental switch in GABA(A)-mediated signaling from excitation to inhibition in CA3 rat hippocampus using gramicidin perforated patch and extracellular recordings. Epilepsia 48 [Suppl 5]:96-105.

Tyzio R, Minlebaev M, Rheims S, Ivanov A, Jorquera I, Holmes GL, Zilberter Y, Ben-Ari Y, Khazipov R (2008) Postnatal changes in somatic gammaaminobutyric acid signalling in the rat hippocampus. Eur J Neurosci 27:2515-2528.

Tyzio R, Allene C, Nardou R, Picardo MA, Yamamoto S, Sivakumaran S, Caiati MD, Rheims S, Minlebaev M, Milh M, Ferré P, Khazipov R, Romette JL, Lorquin J, Cossart R, Khalilov I, Nehlig A, Cherubini E, Ben-Ari Y (2011) Depolarizing actions of GABA in immature neurons depend neither on ketone bodies nor on pyruvate. J Neurosci 31:34-45.

Valeeva G, Abdullin A, Tyzio R, Skorinkin A, Nikolski E, Ben-Ari Y, Khazipov $\mathrm{R}$ (2010) Temporal coding at the immature depolarizing GABAergic synapse. Front Cell Neurosci 4:pii:17.

van den Pol AN, Obrietan K, Chen G (1996) Excitatory actions of GABA after neuronal trauma. J Neurosci 16:4283-4292.

Wahab A, Albus K, Heinemann U (2011) Age- and region-specific effects of anticonvulsants and bumetanide on 4-aminopyridine-induced seizurelike events in immature rat hippocampal-entorhinal cortex slices. Epilepsia 52:94-103.

Wang DD, Kriegstein AR, Ben-Ari Y (2008) GABA regulates stem cell proliferation before nervous system formation. Epilepsy Curr 8:137-139.

Wirrell EC, Armstrong EA, Osman LD, Yager JY (2001) Prolonged seizures exacerbate perinatal hypoxic-ischemic brain damage. Pediatr Res 50:445-454.

Wusthoff CJ, Dlugos DJ, Gutierrez-Colina A, Wang A, Cook N, Donnelly M, Clancy R, Abend NS (2011) Electrographic seizures during therapeutic hypothermia for neonatal hypoxic-ischemic encephalopathy. J Child Neurol 26:724-728. 